\title{
Early modern English drama and visual culture
}

This book discusses early modern English drama as a part of visual culture. But what is visual culture, and why use this phrase in place of the 'fine arts' or the 'visual arts'? In part, this choice is motivated by my concern with exploring the plays in their historical contexts. Shakespeare and his contemporaries would not have recognised the phrase 'fine arts'. Nor would they have recognised the categories that we might now refer to as the 'decorative arts' and 'crafts', these terms being products of the eighteenth century. ${ }^{1}$ It is partly because the phrase 'fine arts' is anachronistic for the early modern period that I avoid its use throughout this book, although I frequently discuss visual representations which are identified with this aesthetic category, such as paintings and sculpture. Instead, in this study I approach drama as a part of visual culture, and, within this broad approach, I refer to visual representations and occasionally to the visual arts. These phrases are all as anachronistic as is 'fine arts' for a discussion of early modern culture, and so my terminology requires further qualification. To this end, this chapter explores what is meant by early modern English visual culture, and expounds my approach to drama as a part of that visual culture.

The phrase 'visual culture' emerged in art-historical criticism in the late twentieth century, and is usually used with reference to modern and postmodern visuality, although it is notable that the first allusion to 'visual culture' is in Michael Baxandall's pioneering 1972 study, Painting and Experience in FifteenthCentury Italy. 'Visual culture' is a pertinent phrase for use in this study because it implies a breadth of visual reference that includes the diverse range of types of work with which an early modern artisan might be involved. Painters in this period regularly carried out decorative work, and, as Lucy Gent points out, paintings in the late sixteenth and early seventeenth centuries were to some extent 'thought of as forms of surface and wall-cladding'. ${ }^{3}$ For example, active in the early seventeenth century, Rowland Buckett was a painter whose 'forte lay in decorative painting' but was also expert in 'gilding, joinery, and carving'. ${ }^{4}$ Examples of his work survive, such as his decorations of a chamber organ made by John Haan and dated to 1611-12, at Hatfield House (figure 1). ${ }^{5}$

In this swirling composition depicting intertwined bodies of animals, mythical 


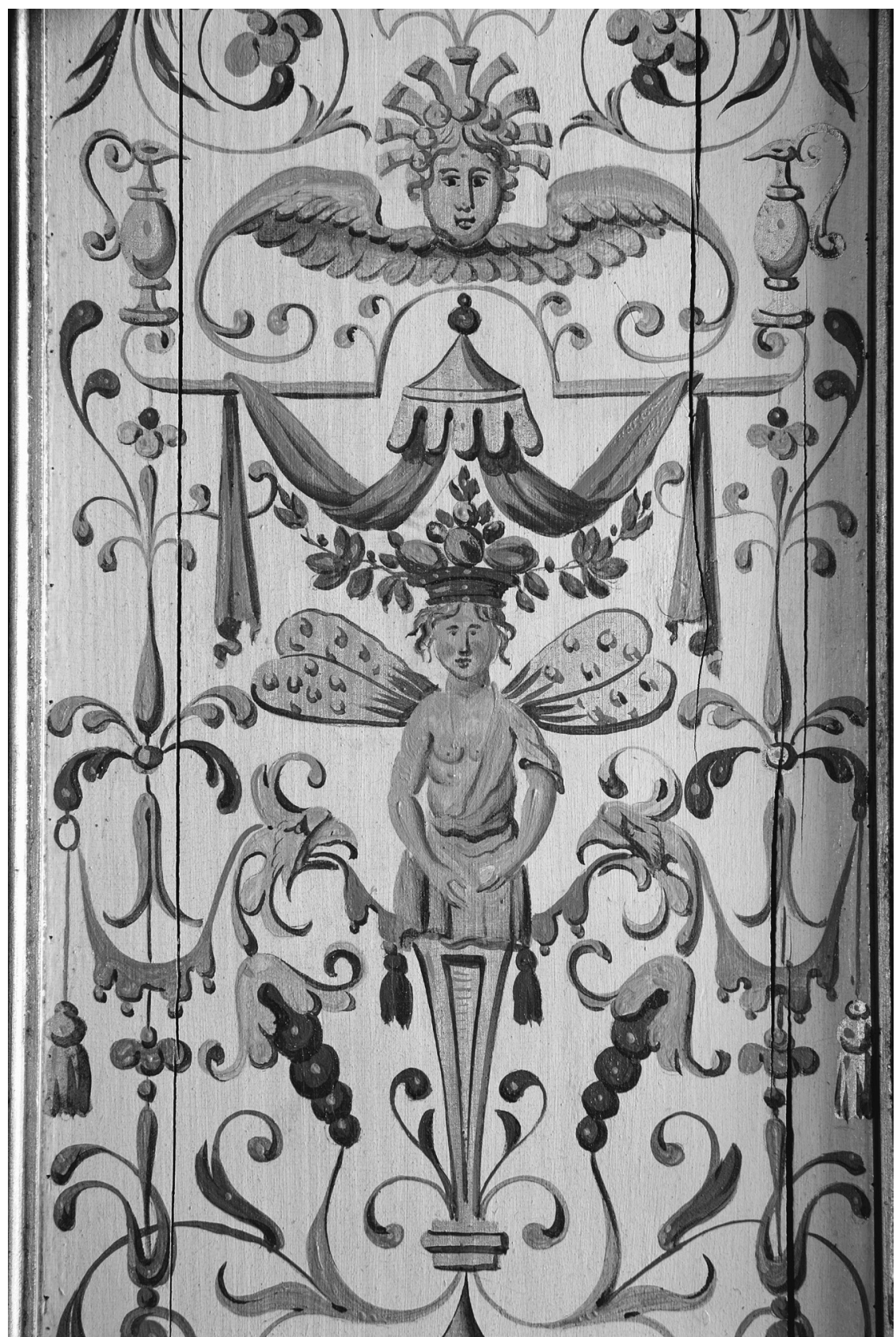

1 Rowland Buckett, detail of painted decoration of John Haan's chamber organ at Hatfield House (1611-12) 
beasts and semi-human figures, Buckett, the son of a German refugee, 'adapted a plate from Newes Gradesca Büchlein, a suit of grotesques designed by the engraver Lucas Kilian (1579-1637) and published in Augsburg in 1607'. ${ }^{6}$ This type of grotesque design is also known in the period as 'antic work', as in John Florio's 1598 Italian-English dictionary, where 'grottesca' is defined as 'a kinde of rugged unpolished painters worke, anticke worke' ?

By 1611 Buckett was relatively experienced in organ decoration, as in 15991600 he travelled with the organ-maker Thomas Dallam to Constantinople in order to deliver to Sultan Mehmed III the diplomatic gift of an elaborate organ that also functioned as a clock. ${ }^{8}$ A versatile figure, Buckett was closely connected to the world of early modern drama, working for Edward Alleyn from 1612, and even selling Alleyn 'painter's pigments and gold and silver leaf. ${ }^{9}$ The painter also collaborated with Thomas Middleton on the production of the Lord Mayor's Show, The tryumphs of honor and industry (1617), and worked on the set for James Shirley's masque The Triumphs of Peace, performed at the Middle Temple in 1633. ${ }^{10}$

Buckett's versatility was not unusual in this period. Life as what might be termed a 'visual artist' in early modern London seems to have often involved a variety of types of work in collaborative contexts. The painter John De Critz produced portraits of James I and Anne of Denmark in 1605-6, but as Sergeant Painter to the king he also carried out decorative work, such as 'Cullouring in Gould cullor the Braunches of ... Candlesticks in the Cockpitt', and also scene-painting for masques, such as 'payntinge ... a greate arche with two spandrels, two figures and two pillasters' in the Banqueting House for the performance of Thomas Campion's Masque of Squires on 26 December 1613. ${ }^{11}$ Inigo Jones, the most well-known stage designer to work on the Stuart court masques, was, famously, an architect, appointed Surveyor-General of the King's Works in $1615 .{ }^{12}$ In 1630 , this role included passing 'Designes and Draughtes' for 'woorkes about the Cockpitt and Playhouse there' to De Critz, who then directed 'Carvers and Carpenters' in implementing the designs. ${ }^{13}$ That painting was connected to a range of other practices is also suggested by the treatises on drawing and painting which emerge increasingly in the early seventeenth century. For example, Henry Peacham's The Gentlemans Exercise (1612), which was also published with a different title page as Graphice, discusses 'drawing' and 'the making of all kinds of colours' for the benefit of 'all yong gentleman' as well as 'Serving for the necessarie use and generall benefite of divers Trades-men and Artificers, as namely Painters, Joyners, Free-masons, Cutters and Carvers'. ${ }^{14}$ One of Peacham's later works, The Compleat Gentleman (1622), discusses 'Drawing and Painting in Oyle' as one of the many practices appropriate for gentlemen, in addition to 'Cosmography' and 'Musicke'. ${ }^{15}$ John Bate's The Mysteryes of Nature, and Art (1634), meanwhile, is divided into four sections; the third covers 'Drawing, Limning, Colouring, Painting, and Graving', while the other sections are devoted to waterworks, fireworks and 'divers experi- 
ments' termed 'Extravagants'. ${ }^{16}$ The title page to Bate's work shows a man painting in the bottom left corner, alongside images of fireworks and contraptions for the production of waterworks (figure 2). In the bottom right corner is a 'frame' that functions along loosely perspectival lines and is recommended by Bate for the depiction of 'a Towne, or Castle'. ${ }^{17}$

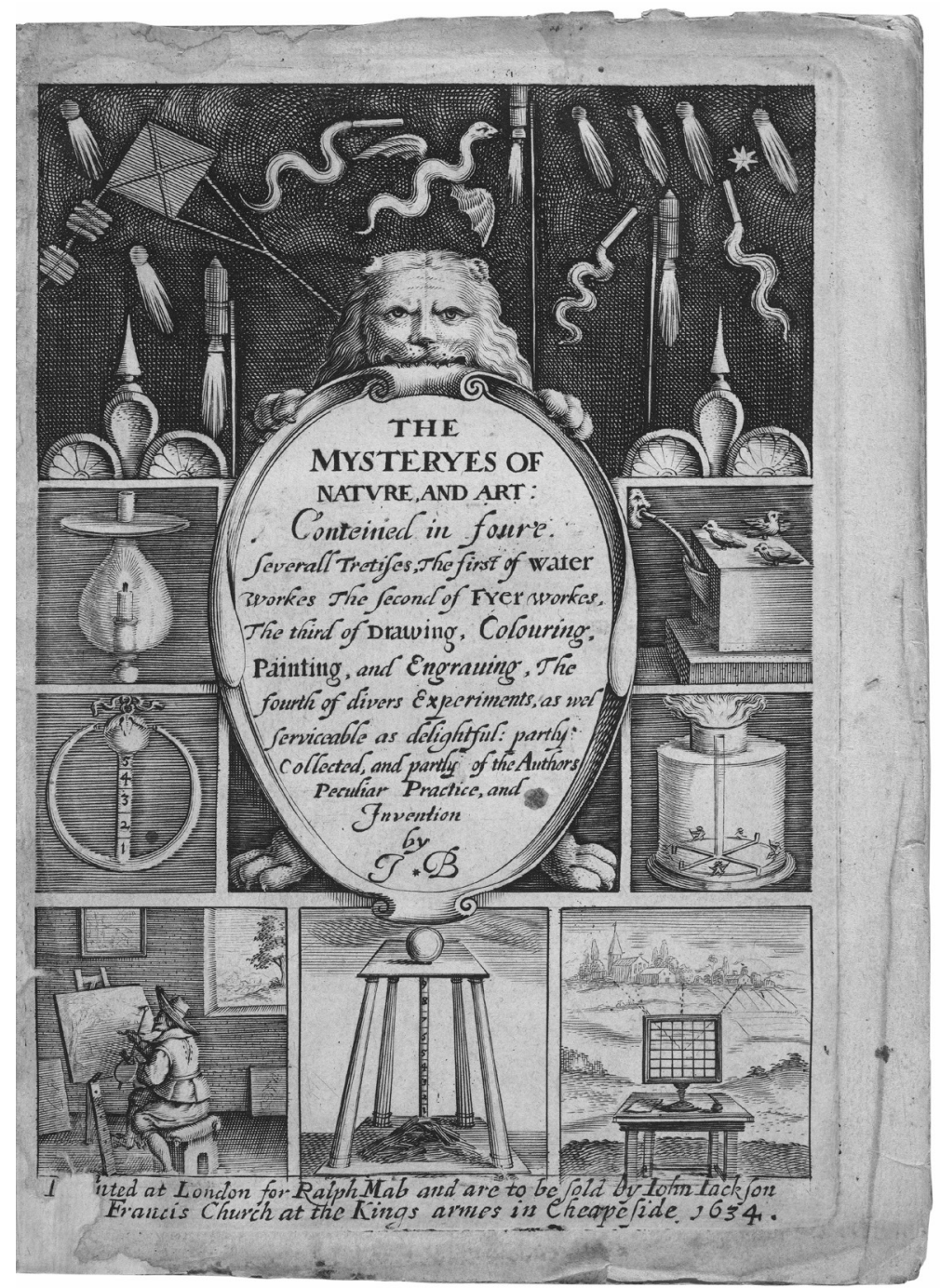

2 John Bate, The Mysteryes of Nature, and Art: Conteined in foure severall Tretises, The first of Water workes the second of Fyer workes, The third of Drawing, Colouring, Painting, and Engraving, The fourth of divers Experiments, as wel Serviceable as delightful: partly Collected, and partly of the Authors Peculiar Practice, and Invention, by J. B (1634), title page 
It is against this backdrop of professional versatility that I have chosen to refer to 'visual culture' as opposed to 'the visual arts' or 'the fine arts'.

At its broadest, visual culture can mean anything that is seen. ${ }^{18}$ Visual culture thus also implies the 'visual field', but the term 'culture' usefully invokes the production of representations as a part of that field. Moreover, 'culture' collapses the disciplinary divisions between visual and literary modes of representation in ways that are useful for an interdisciplinary study that looks between modes of expression sometimes understood as distinct. As a constituent of the visual field, it is possible for a play in performance to participate in visual culture in a direct way that does not seem as plausible with reference to the visual arts, although that Shakespeare is 'himself a visual artist' is sometimes claimed. ${ }^{19}$ In addition, the use of the word 'culture' directs us away from the idea of imagemaking and playwriting as the setting up of a representational object, focusing attention instead on representational activity as 'process'. Raymond Williams states that 'culture in all its early uses was a noun of process; the tending of something, basically crops or animals'.$^{20}$ Culture thus implies an action in process, on-going, fermenting, subject to change; a state of affairs that I will argue characterises dramatists' metatheatrical engagements with the idea of representation. As I explain in the next section, this association between visual experience and matter subject-to-change is also highly pertinent for post-Reformation English visual contexts.

\section{Re-formation visual culture}

By the late sixteenth and early seventeenth centuries, English visual culture had experienced tumultuous changes resulting from the religious reforms that began to take effect in the late 1530s. In pre-Reformation devotional practices, the relationship between worshipper and God was extensively mediated through visual representations depicting Christ and the saints. Medieval English churches were 'filled' with images of the saints, the embellishment and upkeep of which was paid for by worshippers. ${ }^{21}$ Decorated shrines held relics of the saints in containers 'overlaid with decorative plates of gold and silver and the jewels given by generations of pilgrims'. ${ }^{22}$ Individuals purchased devotional images carved in alabaster depicting scenes from the Passion, or 'iconographical types such as the Lamentation, Christ as the Man of Sorrows and St. Anne with the Virgin and Child'. ${ }^{23}$ The centrality of visual representations in Christian devotion in England was overturned by the Protestant Reformation, which insisted that man's relationship with God be mediated through Scripture and therefore denied the place of images in spiritual communion. ${ }^{24}$ Christians had long debated the function of images in spiritual life, but the reformist emphasis on the primacy of the word was now directly invested in the identification of religious images as idols; as distracting 'false' representations. ${ }^{25}$ As a result, 
during the reforms of the early sixteenth century, images were destroyed and removed from churches; wall paintings depicting the saints were whitewashed, the heads and hands of sculptures knocked away or defaced. ${ }^{26}$ Subsequently, and with the exception of the five-year reign of the Roman Catholic Mary I, bursts of state-authorised and popular iconoclasm targeted images in religious, public and domestic spheres. ${ }^{27}$

Interlinked with this attack on visual culture was a destabilisation of theories of vision. In the early modern period 'seeing' was understood as a material, tactile experience, a view based on medieval and classical models which held that 'species' which 'radiated out' from objects 'carried the likeness or "similitudes" of visible forms from object to eye'; the likeness was then 'stamped' on the memory by the 'internal senses'. ${ }^{28}$ Influenced by Neoplatonism and advances in psychology, early modern theorists of vision positioned the imagination as a creative faculty that mediates between the sensory perception of external objects and the intellect, 'constructing, combining, and manipulating' the images with which the latter is supplied. ${ }^{29}$ In this view, perception implies a mental process of image-making mediated by an imagination that is able to 'recreate, recompose, and relocate images'. ${ }^{30}$ Because early modern models of vision conceptualised spectatorship as a mode of image-making, 'superstition' was held to exist 'in the mind of the worshipper'. ${ }^{31}$ It was therefore feared that any spectator could fall into idolatrous imaginings in any visual situation. ${ }^{32}$ As is often noted, the playhouses were frequently attacked as idolatrous; the antitheatricalist Stephen Gosson, for example, argued that 'suche men as are erectors of Stage Playes among Christians ... communicate with the sacrifices and idolatry of the Gentiles' ${ }^{33}$

Studies of early modern English drama and visual culture frequently aim to trace the theatre companies' responses to the challenges posed by professional performance in post-Reformation contexts. ${ }^{34}$ Most importantly, Huston Diehl has explored the ways in which the spectacle of the stage might have been adapted to suit a 'Protestant aesthetics'. ${ }^{35}$ Diehl was pioneering in her recognition that theatrical spectacle might form a part of visual culture, yet she ultimately considered a 'Protestant aesthetics' to have been impossibly flawed and self-destructive, playwrights 'killing what they love' as they demystified 'the older, miraculous forms of theatricality'. ${ }^{36}$ Diehl therefore considered early modern English drama to be in process of change as a part of an unstable post-Reformation visual culture headed towards an iconoclastically fatal conclusion. In this, and in her focus on Protestantism as a faith that 'nurtured a deep distrust of the visible', Diehl echoed the widespread assumption that the Reformation fostered deep-seated anti-visual sentiments in England. ${ }^{37}$ As noted in the introduction, it is widely held that early modern English visual culture was in some way deficient, lacking, bereft in the wake of the Reformation. Such a view echoes Patrick Collinson's claim that, during the sixteenth century, 
England moved 'from iconoclasm to iconophobia'. ${ }^{38}$ This narrative of an early modern English visual culture set on a destructive path remains influential. For example, in his two works on literature and visual culture in this period, Knapp builds on Collinson's account of 'Elizabethan iconophobia', although with the acknowledgement that 'a vibrant visual culture continued to thrive on singlesheet prints (mostly ballads and broadsides)' ${ }^{39}$ This reference to a thriving, popular visual culture acknowledges the work of Tessa Watt, who makes an important challenge to Collinson's thesis in her Cheap Print and Popular Piety, 1550-1640. This seminal study traces the vast array of affordable printed images in circulation in England in the late sixteenth and early seventeenth centuries, demonstrating the significance of printed visual material in religious life after the Reformation. ${ }^{40}$

The present book exploits the groundswell of studies that approached the topic of English Protestant visual culture with seriousness in the wake of Watt's pioneering work. I am especially indebted to an important collection of essays on this subject edited by Tara Hamling and Richard L. Williams. Introducing this collection, Hamling and Williams argue that rather than considering the Reformation as signalling 'the end of art' in Britain, we should understand the visual arts in this period as 're-forming', or undergoing a process of 'cultural transformation' that included 'continuities and discontinuities, innovation and destruction' ${ }^{41}$ This approach to the period is most effectively demonstrated in Hamling's work on the function of religious images in Protestant life in England and Scotland in her Decorating the 'Godly' Household: Religious Art in PostReformation Britain. Hamling overturns Collinson's 'flawed notion of iconophobia', and demonstrates that Protestant households were decorated with biblical scenes that played an important role in everyday piety. ${ }^{42}$ Hamling explores the dynamics and nuances of 'Protestant image theory', such as that depictions of Christ and the Virgin Mary 'were widely condemned in a church setting', but 'were not unusual in post-Reformation domestic decoration'. ${ }^{43}$ For example, Hamling shows that New Testament imagery is found in the first-floor chamber of merchants' houses, a room 'almost certainly ... used for household prayers' ${ }^{44}$ Old Testament scenes, meanwhile, were associated with meditation and so frequently appear on fireplace overmantles, the 'site of prolonged viewing, contemplation and possibly discussion'. ${ }^{45}$ Of course, this biblical iconography has no place on the early modern stage, as the depiction of religious subjects in plays was prohibited under the terms of the 1559 religious settlement. ${ }^{46}$ As Catherine Belsey has shown in a study which informs Hamling's work, however, it can be highly profitable to read Shakespearean drama alongside religious visual imagery from the period. ${ }^{47}$ Greater awareness of the types of visual representation that playwrights may have encountered in domestic spaces should surely inform our interpretation of the depiction of visual culture on the early modern stage. 
Recognising that early modern visual culture was not the 'end of art', then, this book is most heavily indebted to Hamling and Williams's conceptualisation of a Protestant visual culture undergoing change. This vision of early modern English visual culture complements my concern with depictions of visual processes and practices in plays, and with reworkable matter as distinct from completed, fully formed objects. In addition, the notion of a visual culture in process of transformation also complements new art-historical work on iconoclasm that I exploit in this study. As noted above, iconoclasm is frequently understood as a symptom of post-Reformation English hostility to images, and the catalyst for the 'iconophobic' rejection of images described by Collinson. Significantly, Collinson recognised that iconoclasm is not in itself 'anti-image', since iconoclastic attacks modify images and so produce new spectacle. ${ }^{48}$ Concentrating on iconophobia, Collinson did not explore extensively what he had implied was a creative side-effect of image-breaking.

Since Collinson's work, a number of studies have revisited the contested meaning of iconoclasm in ways that are useful for my interest in drama as a part of a visual culture in 'process of cultural transformation'. ${ }^{49}$ In an important collection of essays on iconoclasm, many of the contributors explore the proposition that, as Richard Clay explains, image-breaking has a 'creative dimension', given that 'even when an object is utterly erased the empty space that it once filled can connote new meanings for as long as the absent signifier is remembered'. ${ }^{50}$ Such an interpretation locates the iconoclast as a spectator who views an image in order to destroy or deface it, and simultaneously becomes a 'maker' in iconoclastically producing 'a new signifier that points to new meanings' ${ }^{51}$ Michael Wayne Cole and Rebecca Zorach, similarly, write that 'accusations of idolatry' in the early modern period are significant because 'such accusations did not just concretize the idol in an act of destruction: it likewise resulted in the making of new things' ${ }^{52}$ What is most important for my study is what iconoclasm may tell us about early modern spectatorship. Fabio Rambelli and Eric Reinders, writing on iconoclasm in East Asia, view the destruction of images as a process with transformative implications for the iconoclast as much as for the destroyed object:

The destruction of objects produces new meanings and practices, and damaged things may become more precious. The destruction of religious objects is a cultural practice that changes the materiality or the meaning of the object involved, or both. Destruction and damage of religious objects cause transformations of the semiotic status of those objects ... destruction may also transform the status of the agents involved..$^{53}$

Here, iconoclasm is a transformative process, rather than an event which ends in total destruction for the image and continuation of the iconoclast's status prior to this process. The iconoclast, in this view, is simultaneously a spectator and 


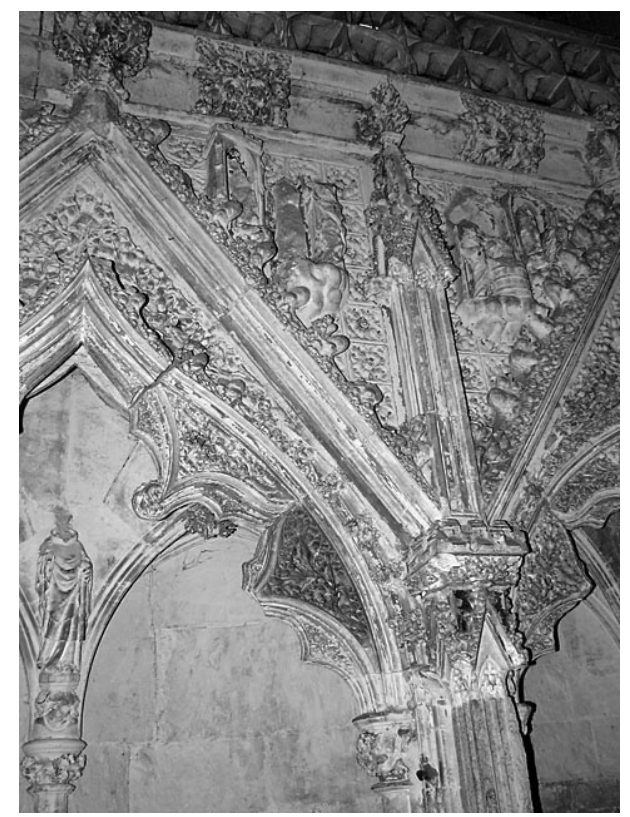

3 Headless statues in the Lady Chapel, Ely Cathedral

(C) Photograph by Evelyn Simak. Creative Commons Licence

maker of an image; they view the image in order to destroy or damage it, but in the process of destruction, they make a new visual item.

This understanding of iconoclasm is applicable to instances of early modern English image-breaking. Iconoclasts in this period would often obliterate the head and hands of an image, leaving it on display in a 'mutilated' state. ${ }^{54}$ This has happened in the case of the headless statues which still stand in the Lady Chapel of Ely Cathedral (figure 3), and also in the defacement of the heads, hands and feet of the saints depicted on a rood screen in St Nicholas' church, Salthouse, Norfolk (figure 4). Leaving behind mutilated figures in both cases, the iconoclasts responsible created new spectacle..$^{55}$

Iconoclasts operated in different ways and with different degrees of violence across the period. For example, archeological examination of fragments of a figure from the shrine of Little St Hugh, Lincoln Cathedral, has revealed that where iconoclasts in 1540 had chipped away at and defaced the head of the figure, image-breaking that probably occurred in a major attack on the Cathedral in 1644 required that the already defaced head be 'knocked off the structure'. ${ }^{56}$ Thus seventeenth-century iconoclasts reworked century-old defacement in a more violent act of signification. A different kind of remaking is evidenced by wall paintings in the parish church of St Lawrence, Eyam, in Derbyshire. Here, in around 1600, in response to the prohibition on depictions 


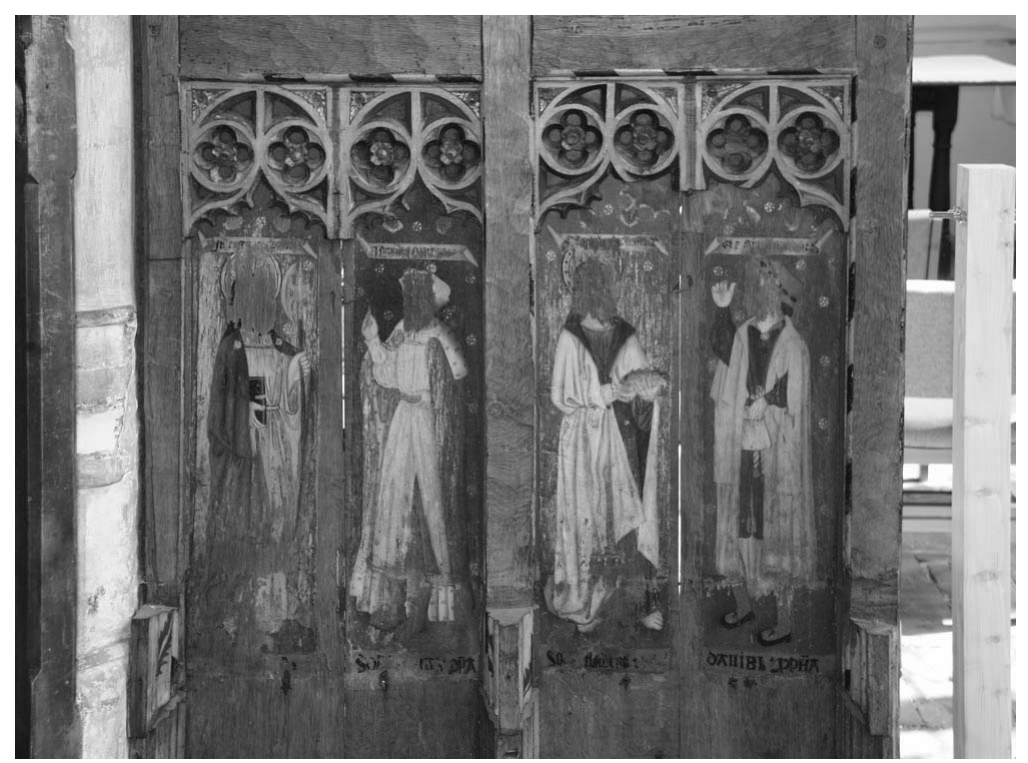

4 Rood screen panels showing defaced figures, St Nicholas' church, Salthouse, Norfolk.

(C) Photograph by John Salmon. Creative Commons Licence

of Christ and the saints, a series of wall paintings showing the ensigns of the twelve tribes of Israel were painted either side of the chancel arch, either side of the belfry arch, and on the north and south walls of the church. ${ }^{57}$ These paintings replaced earlier images, now lost, and in about 1620 were also 'replaced by a third design ... a fragment of the Creed'. ${ }^{58}$ All of the images were covered up in the 1640s, and not uncovered until the nineteenth century; a medieval depiction of a skeleton was also uncovered, this image presumably having been whitewashed during the initial sixteenth-century reforms. ${ }^{59}$ The interior of Eyam parish church therefore attests to a long early modern history of iconoclasm and remaking, in which the production of images is interlinked with the destruction of others.

Can we understand post-Reformation iconoclasm as a form of interactive spectatorship, in which viewers participate in a process of continual remaking within visual culture? And given that iconoclastic attitudes are taken to have extended to visual culture more broadly, can we then apply this model of spectatorship to the experience of watching a play in post-Reformation England? The applicability of this model is suggested by the many instances in which plays are depicted as 'under construction' at the hands of audience members. In the next section, I explain in more detail my approach to the interactive function of the spectator in drama and visual culture. 


\section{Ways of seeing: spectators as 'makers'}

The prologues and epilogues performed on the commercial stages of early modern London frequently draw attention to the significance of spectators as participants in the construction of meaning. For example, The Travels of the Three English Brothers, by John Day, William Rowley and George Wilkins, first performed and published in 1607, opens with a Prologue in which the audience are told that the 'scene' of Sir Anthony Sherley's journey to Persia 'lies speechless, active but yet dumb, / Till your expressing thoughts give it a tongue'. ${ }^{60}$ The Epilogue to John Ford's The Broken Heart suggests that if the 'best' of the audience are pleased with the production then 'the Broken Heart may be piec' $\mathrm{d}$ up again'. ${ }^{61}$ To take a further, very well-known example: in the prologue to Shakespeare's Henry V (probably first performed in 1599), spectators are invited to use their 'imaginary forces' to conduct piecemeal processes of assemblage while watching and imagining the events of the play. ${ }^{62}$ Alert to the inability of the 'unworthy scaffold' of the stage to convey 'the vasty fields of France', this prologue suggests collaboration between production and audience:

O pardon: since a crooked figure may

Attest in little place a million,

And let us, ciphers to this great account,

On your imaginary forces work.

Suppose within the girdle of these walls

Are now confined two mighty monarchies,

Whose high upreared and abutting fronts

The perilous narrow ocean parts asunder.

Piece out our imperfections with your thoughts.

Into a thousand parts divide one man

And make imaginary puissance.

Think, when we talk of horses, that you see them

Printing their proud hoofs i' th' receiving earth.

For 'tis your thoughts that now must deck our kings,

Carry them here and there, jumping o'er times

Turning th'accomplishment of many years

Into an hour-glass. ${ }^{63}$

Here, audience members are invited to view the scenes that are to be presented to them as visual and material items subject to alteration. Audience members are enlisted in the dressing of the bodies of kings in the play, since, as the OED suggests, all late sixteenth-century interpretations of the verb to 'deck' relate to this act. Similarly, the invitation for spectators to mentally 'piece out' the production in order to compensate for the play's failings refers to the construction of visual appearance. According to the OED, the earliest meaning of 'piece' as a verb, still current in the sixteenth century, was 'to mend, make whole or ... 


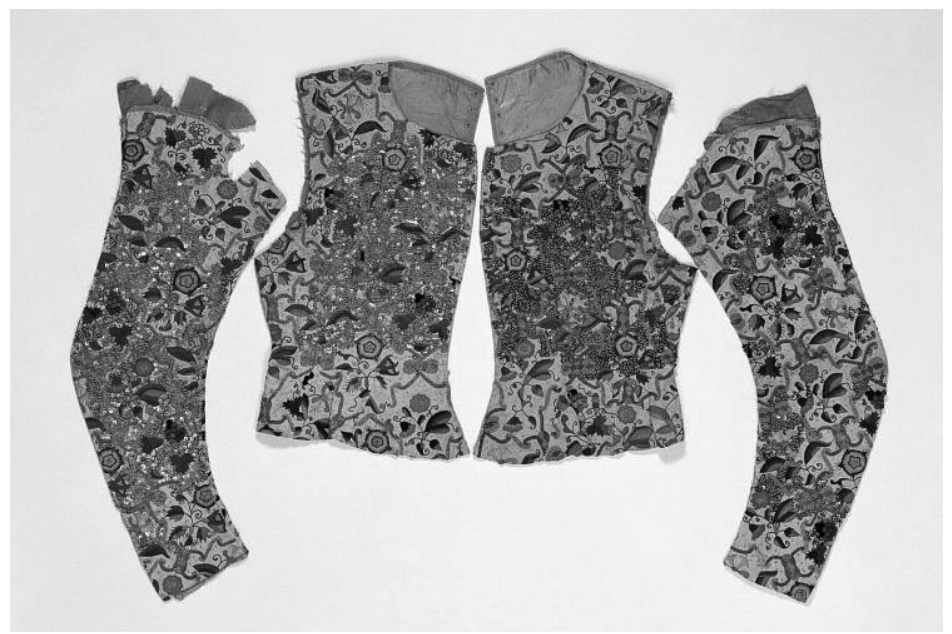

5 Jacket, possibly remade for masquing (1600-20), (C) Victoria and Albert Museum, London

patch', with the first known use of this word being in reference to the piecing of a 'clout hem of sacchis or opere pecis' ${ }^{64}$ The practice of patching and piecing together items of material and dress would have been familiar to spectators from all levels of society. As Ann Rosalind Jones and Peter Stallybrass explain, 'the value of clothes was ... directly connected to the expense of the materials from which they were made', and so such materials would long outlive their initial usage in a culture in which 'fabrics were reused by rich and poor alike'. ${ }^{65}$ An embroidered silk jacket dated to $1600-20$ is thought to have been remade decades into its lifetime for use in masquing, with extra spangles added to catch the light in performance (figure 5).

Below the level of the elite, most people would have had experience of mending their own clothes; a rare survival of a full sailor's outfit in the Museum of London, for example, shows heavy patchwork where the thick woollen cloth has been repaired (figure 6).

Early modern clothing 'was a composition of detachable parts', with the dress of wealthy and aristocratic men and women in particular requiring the assemblage of a significant number of different items. ${ }^{66}$ As a result, 'dressing and undressing were social processes that required ... other pairs of hands' ${ }^{67}$ The construction of the spectator as a participant in visual and material culture in Henry $V$ therefore draws on processes which would have been familiar to playgoers from the experience of piecing together their own visual appearance, or helping to compose the dress of relatives, friends, masters, mistresses or clients.

As noted above, playwriting was commonly understood as the piecing together of 'odds and ends'; it was on this basis that playwrights were known as 'play-patchers' ${ }^{68}$ Material and literary modes of piecing together intersect here, 


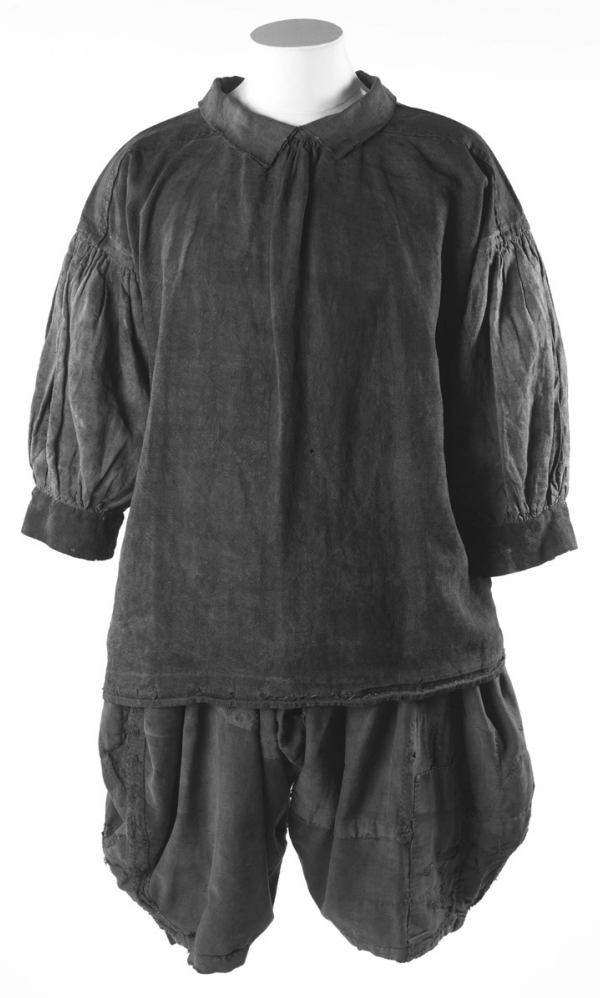

6 Shirt ensemble (1600-1700), (C) Museum of London

as, the OED explains, to 'piece out' was a newly developed phrasal verb in the late sixteenth century, meaning 'to enlarge or complete by the addition of a piece'. For example, George Puttenham deploys the phrase in the context of poetic composition when he notes 'how much better some bissillable becommeth to peece out an other longer foote then another word doth'. ${ }^{69}$ The prologue to Henry $V$ thus appeals to spectators through terminology invoking literary, material and visual compositional practices. I draw attention to this combination of literary, material and visual contexts in order to emphasise that while I am concerned with drama as a part of visual culture, other types of sensory experience and modes of expression are important for my analysis. Work on the early modern senses paints a picture of Reformation sensory experience in which different types of perception converge and overlap. For example, in an important reorientation of conventional critical thought on Reformation sensory experience, Matthew Milner points out that the word which replaced the image in sixteenth- 
century reforms also took on roles previously supplied by images; the word was thus 'visual and aural, ... touched, eaten and smelled' ${ }^{70}$ Such a sensory overlap is arguably encouraged by the dynamics of performance and reception in early modern theatre. Playwrights' allusions to and depictions of visual experience are verbal in the sense that they are produced by writing and speech, and 'visual' in that their performance always entails some degree of spectacle. The player speaking the Prologue at the opening of Henry $V$ draws attention to the lack of visual content presented on stage, yet his standing on that stage at all constitutes spectacle. That theatre companies considered even the barest of onstage moments as part of a visual composition is indicated by the fact that players who delivered stage orations such as prologues frequently wore a 'Prologue uniform', often a laurel wreath, that denoted the speaker's function. ${ }^{71}$

In speaking of spectators' visual and sensory experiences of plays in performance, I do not mean to allude simplistically to audience members as individual agents. Gurr has pointed out that spectators are individual viewers, whereas "“audience" is a collective term for a group of listeners'. ${ }^{72}$ The tension between the experience of the individual watching a play and the collective experience of a group that constitutes an audience has been the scene of extensive debate, most prominently in Anthony B. Dawson and Paul Yachnin's collaborative discussion of early modern English playgoing culture. ${ }^{73}$ It seems reasonable to adopt a view of early modern playgoing that recognises distinctions and the importance of 'negotiations' between 'individual' and 'collective' experiences, but which suggests that collective experience was constituted by playgoers' individual perspectives. ${ }^{74}$ In this approach I build on Charles Whitney's work on playgoers' responses to early performances of the plays of this period. Whitney emphasises diversity in dramatic reception, and therefore calls attention to the ways in which individual reactions to plays in performance might emerge from collective audience experiences. ${ }^{75}$ I also avoid the identification of different 'types' of playgoer, a subject which has received significant attention, particularly in regards to the contrast between 'seeing' and 'hearing'. ${ }^{76}$ Such a focus is encouraged by certain examples from the plays, and particularly works by Ben Jonson. For example, the Induction to Bartholomew Fair (first produced 1614) distinguishes between 'spectators and hearers'. ${ }^{77}$ In a later play by Jonson, The Staple of News (first performed 1626), the Prologue for the Stage declares that Jonson would 'have' playgoers be 'wise, / Much rather by your ears, than by your eyes' ${ }^{78}$ There is scope for taking these allusions to opposing modes of playgoing as reflective of a Jonsonian paragone debate. ${ }^{79}$ Jonson's disparaging reference to those who are satisfied by that which pleases the 'eyes' in The Staple of News can convincingly be linked to the playwright's infamous quarrel with Inigo Jones, with whom Jonson had collaborated on the Stuart court masques since 1605 , and whom he seems to mock in parts of this play. ${ }^{80}$ Yet how can the divisions between 'spectators' and 'hearers' encouraged by Jonson be related 
to the fluid sensory experience evoked in the prologue to Henry V? One way to approach this apparent inconsistency is to acknowledge that in line with early modern English visual culture more broadly, concepts of spectatorship were in transition during this period.

According to the $O E D$, during the late sixteenth century 'spectator' emerged as a new term meaning 'one who sees, or looks on at, some scene or occurrence; a beholder, onlooker, observer'. The earliest usage of this term noted in the OED is from Sir Philip Sidney's The Countesse of Pembrokes Arcadia, where Plexirtus trusts 'no eyes of sufficient credite in such a matter, but his owne' in the murder of his brother, 'and therefore came him selfe to be actor, and spectator' ${ }^{81}$ The first edition of this work was published posthumously in 1590, and 'spectator' appears in this revised version, which Sidney wrote in $1584 .^{82}$ In his still invaluable study of early modern playgoing, Andrew Gurr states that 'the first writer to use the term "spectator" appears to have been ... Philip Sidney' ${ }^{83}$ The earliest usage of 'spectator' in English that I have been able to find is from a much earlier text, The new pollecye of warre (1542), by the reformist theologian Thomas Becon (also known as Theodore Basil), who declares in his Prologue that he has been a 'vayne gazer and idle spectator' ${ }^{84}$ Becon's allusion to being an 'ydle spectator' perhaps illustrates the OED's second meaning for this term, dated to 1590: 'one who is present at, and has a view or sight of, anything in the nature of a show or spectacle'. This definition has clear relevance for the spectatorship of the 'show' presented in the early modern playhouses, but suggests that spectators behold a scene over which they have no control and which functions independently of their gaze. The spectator who passively watches a 'show' does not resemble the interactive figure of the spectator that is invoked both in the plays and by early modern theories concerning the tactility of vision. It might be suggested that our understanding of spectatorship in the early modern theatre remains incomplete, and that in early modern London the relatively 'new' context of commercial theatre offered a useful but unstable testing ground for ways of seeing.

It is not new to suggest that theatre participates in post-Reformation anxieties about visual experience. In a book that extensively influences the present study, Katharine Eisaman Maus suggests that early modern spectacle, including theatrical spectacle, depends on semi-hidden, 'ambiguous' truths, and so reflects the period's 'chronic doubts about the adequacy of what can be seen'. ${ }^{85}$ Decades since Maus's study, and building on Stuart Clark's work on the history of vision, Knapp has explored the ways in which Shakespeare's works address the ethical choices presented by a visual world in which access to a stable 'truth' is uncertain. ${ }^{86}$ In this book, I build on Maus and Knapp's sense that playwrights are concerned with the location of 'truth' in an uncertain visual world, but connect this to the interactive, material practice of spectatorship in a changing visual culture. In this view, spectatorship involves engagements with the materiality of the viewed which act as a source of knowledge, both about the viewed and about 
the viewer themselves. In this approach I connect the act of spectating with the ontological implications of 'the maker's knowledge tradition' as discussed by Elizabeth Spiller. ${ }^{87}$ This tradition rejects an Aristotelian divide between 'praxis or poesis' and scientific knowledge, enforcing the integral relationship between mechanical practice and cognition. ${ }^{88}$ As a result, 'being able to make something was an act of knowledge; knowing something involved knowing how to make it'. ${ }^{89}$ Against this backdrop, acts of viewing which engage with material praxis develop a connection between looking and knowing.

When plays depict or allude to the practicalities that construct spectacle, viewers are invited to reflect on their own status and function in relation to that which they view. For a useful example, I return here to Bartholomew Fair, which concludes with a puppet play put on by the hobby-horse seller Lantern Leatherhead. In the course of this puppet play, Zeal-of-the-Land Busy, a Puritan, enters the audience in the play-world and calls for a halt to the production on the grounds that it is idolatrous. Persuaded by other characters to defend his 'quality', Leatherhead declines to enter into 'disputation' with Busy, but instead presents 'the Puppet Dionysius' to 'venture the cause on't' (5.5.33-7). Idolatrously entering into an argument with a puppet, Busy tells Dionysius that his 'main argument against you is that you are an abomination; for the male among you putteth on the apparel of the female, and the female of the male' (5.5.96-8). Busy here refers to one of the central objections to the theatre as an arena which staged transvestism..$^{90}$ The puppet's response to this accusation leaves Busy 'confuted' and 'converted' to 'a beholder' (5.5.111-15). Dionysius tells his opponent:

It is your old stale argument against the players, but it will not hold against the puppets; for we have neither male nor female amongst us. And that thou mayst see, if thou wilt, like a malicious purblind zeal as thou art!

(The puppet takes up his garment).

$(5.5 \cdot 101-15)^{91}$

The Puppet Dionysius's self-exposure points to the extent to which this study is interested in early modern drama as 'an art of incompletion: a form of display that flaunts the limits of display', to borrow Maus's terms. ${ }^{92}$ Writing from a new-historicist perspective, Maus views playgoers as either 'structured' by the experience of watching a play or resistant to 'the imposition of that structure'. ${ }^{93}$ The example of Busy's interactions with the puppet, in contrast, demonstrates the complicity of the spectator in the production of the incompleteness that is 'flaunted' in drama of this period. ${ }^{94}$ Here, it is the revelation of the material, sexless base (or puppeteer's hand) beneath the external appearance of the puppet that allows Busy to reconfigure his attitude to playgoing and theatrical spectacle. Recognising the nuts and bolts that 'make' that which he views, Busy understands the nature of his role as viewer. Moreover, it is through the process 
of defacement in the alteration of the appearance of the puppet that Busy is converted to a confident and secure 'beholder'. Aura Satz has shown that it is not too much to associate this alteration in the surface of the Puppet Dionysius with the broader iconoclastic context in which defacement and desecration are reasonable responses to visual representations. ${ }^{95}$ Jonson thus uses the dynamics of iconoclasm to convert an iconoclastic antitheatricalist to a willing participant in the construction of onstage meaning. This instance therefore exemplifies the relevance of image-breaking as image-making for the playhouse, and so draws attention to defacement as a productive mode through which spectators may engage with the viewed. It is worth noting here that Busy does not touch the puppet; as is discussed in the next chapter, touch in this period is not a secure route to ontological certainty. ${ }^{96}$ Understanding of the material construction of the puppet offers the Puritan clear parameters through which to configure and understand his relationship to and distinction from the puppet. Busy's conversion, however, also acknowledges that he cannot fully 'know' the nature of spectacle, that there is always something in representation that is beyond material knowledge.

Throughout this study, I focus on the display of incompletion, half-finished works and things that are 'under construction' as moments at which playwrights reflect broadly on representational activity and their own place within this. It is not a coincidence that I allude to playwrights' 'place' within an implicit representational hierarchy. Cultural production in early modern England is extensively shaped by the period's theologically informed concepts of social hierarchy. The concept of representation is founded on the hierarchical relationship between man and God, since creativity is divine, but representation is an imitation of the divine; as Barbara Johnson points out, 'human language in no way resembles the creative word'. ${ }^{97}$ The act of representation is, then, always a flaunting of limitations by comparison to the boundless creative reach of divinity. In later chapters I explore the extent to which deference to divine creation shapes dramatists' preoccupation with unfinished images and the depiction of processes of making in which the reaching of a conclusion is endlessly deferred. Harris understands early modern matter as 'a species of 'arche-writing' in Derrida's sense, inasmuch as it is characterized by an ontological and temporal self-differentiation and hence deferral'. ${ }^{98}$ In this study I consider depictions of making and unmaking in plays as a mode of this early modern 'arche-writing' that posits a response to aesthetic limitations associated with divine hierarchy.

Before encountering this Derridean reading of early modern attitudes to creativity and representation, however, it will be useful to understand in more detail the hierarchical nature of early modern visual culture at a more local level. With the exception of a brief consideration of the diverse roles occupied by 'visual artists', this chapter has thus far considered image-making and its reception as activities undertaken by relatively anonymous figures more or less divorced 
from social contexts. In order to fully understand the extent to which imagemaking in post-Reformation England is inextricable from social hierarchy, it is necessary now to consider in more detail the hierarchical relationship that is at the centre of visual transactions in this period: patronage. As I shall explain, this is a context which is of great interest to dramatists, and which has much to tell us about attitudes to making and unmaking in this period more broadly.

\section{Patronage, image-making and authorial agency}

In each chapter of this book I discuss a play that depicts instances of the patronage of a visual representation. In other words, the processes of visual construction discussed here are connected to commissions made by patrons who also function as onstage spectators. In The Winter's Tale, Paulina is patron of the supposed statue of Hermione; in Lyly's Campaspe, Alexander the Great commissions a portrait of Campaspe, while in Friar Bacon and Friar Bungay, Friar Bacon oversees a demonic image-making process. Since The Two Merry Milkmaids concerns spectatorship within the visual field rather than of a specific artwork, there is less emphasis on patronage in this play. Even here, however, an invisible character commissions a portrait from a low-quality painter who cannot even see his subject. The faultiness of the commission in this latter play is indicative of the instability of patronage of the visual arts in the dramas discussed here overall. In each instance, commissioning processes produce items that never reach a state of 'finish' and therefore remain as reworkable matter.

Despite this apparent emphasis on 'failed' processes of image-making, it should not be surprising that the patronage of the visual arts was an appealing subject for the collaborative world of early modern theatre, because the commissioning of visual representations was a highly collaborative process. In subsequent chapters I will be interested in what these depictions of unfinished works tell us about early modern attitudes to the process and results of cultural production. For now, however, it is worth noting that certain commentators associate English patronage of the visual arts with the production of highly unsatisfactory results. Richard Haydocke, for example, considers interaction between the patron and visual artist to be at the root of what he perceives to be the lamentable state of the visual arts in Elizabethan England. Explaining his purpose in preparing his 1598 English translation of Giovanni Paolo Lomazzo's Trattato Dell' Arte Della Pittura, Scoltura, Ed Architettura (1584), Haydocke touches on the subject of patron-painter relations:

My final reason is plaine: the increase of the knowledge of the Arte; which though it never attained to any greate perfection amongst us (save in some very feawe of late), yet it is much decayed amongst the ordinarie sorte, from the ancient mediocritie, for these 2. causes: First the Buyer refuseth to bestowe anie greate price on a peece of worke, because hee thinkes it is not well done: And the Workemans answere is, that he therefore neither useth 
all his skill, nor taketh all the paines that he could, because hee knoweth before hand the slenderness of his reward. That bothe these obiections might be taken away, I have taken the paines, to teach the one to judge, the other to worke. ${ }^{99}$

Rather than discussing the 'buyer' and the 'workeman' as co-makers of a visual object, Haydocke portrays patron and artisan as complicit in the production of a paralysis in the making process. Although this prefatory material introduces a work which instructs on pictorial technique, Haydocke implies that painters are sufficiently skilled but do not 'worke' in a way that utilises their full abilities, given that the 'buyer' does not give any economic incentive or the encouragement of praise, respect and high expectations. The patron, in Haydocke's view, is the source of this inert dysfunction in making; because the buyer cannot 'judge', the painter does not 'worke' to a sufficient standard. The making of a commissioned object is here dependent on the well-informed spectatorship of the client. For Haydocke, this failure on the part of the client is linked to a lack of knowledge about the visual arts in comparison with that which is available on the continent, hence his project of making Lomazzo's text available to an English-speaking readership.

Haydocke's critique of the 'buyer' and the 'workeman' is frequently quoted as evidence of the underwhelming condition of the post-Reformation English visual arts. ${ }^{100}$ The dominant view that early modern English visual culture is unworthy of serious study has meant that scholars of early modern drama have looked tentatively to the continental visual arts in order to discuss models of patronage. Asking 'what is a text?' in 1991, Stephen Orgel used negotiations between Filippo Lippi and Inigo Jones and their respective patrons as an analogy for the network of exchange from which the early modern text is produced. ${ }^{101}$ Discussing the collaborative nature of Shakespeare's 'late' work, meanwhile, Gordon McMullan notes that 'the late work of Renaissance painters ... is to a surprising and perhaps uncomfortable degree collaborative'. ${ }^{102}$ McMullan is cautious about the usefulness of analogies between Shakespeare and 'Renaissance painters', finding that 'it would obviously be inappropriate to draw too close a comparison between the Renaissance studio system and Elizabethan/Jacobean theatrical collaboration' ${ }^{103}$ It would be inappropriate to overemphasise analogies between early modern English writers and painterly practice in Renaissance Italy, but McMullan overlooks the fact that collaborative practices were commonplace in late sixteenth- and early seventeenth-century English visual culture. Although in provincial English workshops master painters employed very few journeymen or apprentices, in the metropolitan workshops that may have been known to London playwrights and playgoers, several painters often worked collaboratively on portrait production. ${ }^{104}$ Moreover, the production of a visual image frequently involved extensive collaboration between the visual artist(s) and the patron(s) who commissioned the work. When Inigo Jones 
submitted annotated costume sketches to Anne of Denmark from which she then 'made whatever alterations in the design that she wished', the architect and designer of the court masques was not introducing a new continental practice, but working in the collaborative fashion that was widespread practice in England as well as continental Europe at the time. ${ }^{105}$ As Tittler explains, in early modern England, portraits served 'as a tableau in which the patron and the painter collaborate in determining and arranging the content so that it conveys the desired narrative'. ${ }^{106}$ The planning stages prior to the building of late sixteenth- and early seventeenth-century English houses, meanwhile, 'involved a series of dialogues between the patron, surveyor (master mason), and various craftsmen'. ${ }^{107}$ Similarly, patrons of funeral monuments 'exerted ... strict control over the socially and ideologically sensitive aspects of tomb design', making 'moral and legal demands' that tomb-makers found 'hard to ignore'. ${ }^{108}$

The example of tomb design calls attention to the range of people that could be involved in the production of a commissioned work. Patrons involved in tomb design were usually family members, but this process could also involve 'business agents' who negotiated 'contractual agreements', as well as 'specialists in tomb construction' to consult on the design. ${ }^{109}$ The person commemorated often contributed to the cost and sometimes the design of their monument. ${ }^{110}$ John Donne, for example, wrote the epitaph for his famous monument by Nicholas Stone in St Paul's Cathedral, which shows the poet and former Dean of St Paul's rising from an urn in a winding sheet. ${ }^{111}$ Izaak Walton's claims that Donne designed the monument, posing for its composition by standing on an urn while wearing a winding sheet, have been questioned. ${ }^{112}$ Stepping aside from the accuracy of Walton's account, the story of Donne's involvement in the design of this sculpture demonstrates early modern appetite for the idea of the interactive patron as a figure who collapses the boundaries between imagemakers, collaborative agents, consumers and even the subject depicted.

The story of Donne's efforts as a tomb-designer is instructive in this regard, since literary accounts of image-makers working to commission frequently merge into a single figure the multiple roles associated with commissioning projects. In The Winter's Tale, we hear of Giulio Romano carving the supposed statue of Hermione, but there is no mention of any assistants or auxiliary agents employed on this commission. In the painter additions to the 1602 quarto of Thomas Kyd's The Spanish Tragedy, the bereaved Hieronimo, Knight Marshal of Spain, orders the painter Bazardo to produce an image that will reflect a passage of time covering the periods before, including and after the muder of Hieronimo's son, Horatio. As Hieronimo demands that Bazardo show 'a man hanging, and tottering and tottering, as you know the wind will weave a man' and 'make me curse, make me rave, make me cry', the painter appears as a solitary figure. ${ }^{113}$ Bazardo suggests that his 'name' is reputable and proudly refers to the fame of 'my painting', assuring Hieronimo that he can 'draw a murderer', 
because he has 'the pattern of the most notorious villains that ever lived in all Spain'. ${ }^{114}$ This scene extensively mocks the perceived limitations of artificial representation, a mockery that has been understood as complicit in a broader attack on the pre-Reformation 'devotional gaze' ${ }^{115}$ Bazardo's humiliation is so acute partly because he is such a solitary figure. The completion of the painting demanded by Hieronimo would be impossible for a sizeable, functional team of workmen, but Bazardo's willing agreement that 'yea' the picture can be 'done' seems especially implausible given the solitariness of the painter who is eventually beaten off the stage by Hieronimo. ${ }^{116}$

Depictions of patronage of the visual arts in plays usually focus on the relationship between a lone patron and a lone visual artist. This not only means ignoring the groups of workers who might make a visual representation, but also casting a veil over the institutional commissioning of images that was a part of civic life in provincial English towns and cities as well as in London during the period. ${ }^{117}$ It is unlikely that playwrights did not know about collaborative modes of patronage, since, as in the 1617 collaboration between Thomas Middleton and Rowland Buckett, many dramatists worked with artisans on the production of spectacle for civic pageants and royal entertainments commissioned by the London Livery Companies. ${ }^{118}$ In the playhouses, moreover, dramatists were engaged in the collaborative production of spectacle that was consumed by sizeable crowds of people. In this light, the choice to depict image-makers and spectators as singular figures seems like a missed metatheatrical opportunity. On a basic level, it might be argued that this choice is motivated by practical limitations such as the size of the cast. To some extent playwrights' focus on individual visual artists can also be explained by the combined influence of the discourse of ut pictura poesis and the paragone debates, both of which invite comparisons between a 'poet' and 'painter' in ways that obscure collaborative practices in the contexts of verbal and visual representation. The possible influence of this rhetorical discourse should alert us to the literary nature of playwrights' interests in depicting commissioning processes in their plays. It is well known that notions of authorship were in flux during the early modern period, with Jonson's 1616 publication of a folio of his 'complete works', The workes of Benjamin Jonson, often taken as a foundational milestone in the formation of authorial identity. ${ }^{119}$ Decades earlier, in An Apology for Poetry, Sidney had wrestled with the subversive implications of literary ambition in his suggestion that a poet must defer to and 'give right honour to the heavenly Maker of that maker' (p. 86, 1l. 1-2). If God is divine creator of all, claims to authorial ownership may be taken as idolatrous blasphemy, since in Calvinist terms idolatry was not only offensive on grounds of deceitful misrepresentation, but also because it involved 'the worship of the creature in place of the creator'. ${ }^{120}$

At no point in the plays discussed in this book is a desire to transcend representational limitations expressed, although, as we shall see, The Winter's Tale 
comes quite close. At the same time, there is plenty of evidence that the fit between the dynamics of image-making and the divine, natural hierarchy within which it operated was by no means smooth. It has been established that external symbols such as clothing are invested with great social meaning in this period; it was for this reason that the role of the stage in the transgression of sumptuary legislation and the marketing of new fashions provided a point of focus for antitheatricalists. ${ }^{121}$ Beyond discussions of the status of playwrights as contributors to a lowly, 'impure art', or of the social dimensions of literary patronage, however, early modern attitudes to social propriety and the act of making a literary or visual representation remain underexplored. ${ }^{122}$ This is significant, because who might appropriately produce an image is a source of on-going tension throughout the period.

For example, there is much tension around the propriety of painting as a practice to be undertaken by gentlemen. Tittler explains that in the late sixteenth century 'the most fashionable London-based painters had begun to think of themselves as professionals and gentlemen', but most provincial painters in this period would not have claimed this status. ${ }^{123}$ Although it may be that some early modern English portraits were produced 'by people formally trained in some other craft occupation', most 'painters' of this period trained and worked 'within a guild system or at least a well-established freemanry'. ${ }^{124}$ Alongside these professional painters was a 'small handful of gentleman painters', who painted 'as a hobby and not an occupation'. ${ }^{125}$ A number of writers on courtly and gentle conduct recommended painting as a pursuit suitable for a courtier and unsuitable for those of lower social status. For example, Thomas Hoby's English translation of Castiglione's Il Libro Del Cortegiano, explains:

I remember I have read that the men of olde time, and especially in all Greece would have Gentlemens children in the schooles to apply peinting, as a matter both honest and necessary. And this was received in the first degree of liberal artes, afterwarde openly enacted not to be taught to servantes and bondmen. ${ }^{126}$

Henry Peacham repeats this history of noble painting in The Compleat Gentleman, and also highlights the utility of drawing for those of gentle status, explaining that 'without the helpe' of visual representation, those 'employed' in their 'Countries service in following the warre ... can describe no plot, manner of fortification, forme of Battallia'. ${ }^{127}$ Referring to Peacham's advice on the utility of drawing for those of gentle status, Christy Anderson suggests that an early seventeenth-century manuscript treatise on linear perspective in English and Latin in the British Library was intended for an audience of amateur artists as well as the young men addressed by Peacham in The Compleat Gentleman. ${ }^{128}$ Anderson notes that learning about perspective was a part of 'a general humanist education', equipping a gentleman with the visual skills necessary for battle and land management. ${ }^{129}$ In The Art of Drawing (1606), Peacham links the 
educational benefits of his work to social status, stating that for a 'scholer' in the practices he describes, he would 'make choise of ... a yong Gentleman' ${ }^{130}$ It is worth pointing out that The Art of Drawing is an earlier version of The Gentlemans Exercise, which, as discussed above, is presented as useful for 'Trades-men' as well as gentlemen. Notably, the title page to The Art of Drawing does not refer to this artisanal audience; moreover, in The Gentlemans Exercise Peacham repeats his preference for a 'Scholler' who is a 'young Gentlman' ${ }^{131}$ Overall, Peacham approaches visual representation as a useful, gentle mode of expression with artisanal associations.

Notably, John Bate's accounts of visual practices in his Mysteryes of Nature, and Art do not draw attention to the gentle utility of these practices or any preference for a gentle readership. This may be because Bate's work is a popular 'book of secrets' that discusses painting and drawing alongside other technical, 'scientific' activities that fell under the umbrella of the burgeoning study of natural philosophy in this period. ${ }^{132}$ The practical, 'scientific' application of Bate's instructions on drawing is suggested by the fact that these parts of The Mysteryes of Nature, and Art were copied out by 'the young Isaac Newton' . ${ }^{133}$ I do not wish to claim broadly that social difference held an importance in early modern visual culture that was not found in the world of natural philosophy. That said, it might be tentatively observed that the significance of the social status of the visual practitioner is intriguingly prominent in early modern English writings. For example, concerns about social status inform the miniaturist painter and goldsmith Nicholas Hilliard's The Arte of Limning, which was not published during the author's lifetime, or in full until the twentieth century, and which was one of the earliest works on visual representation written by an English professional visual artist. ${ }^{134}$ It seems that Hilliard was persuaded to write his treatise by Richard Haydocke, who, in the prefatory material to his translation of Lomazzo, promises his readership that the miniaturist will produce 'a treatise of his owne Practise ... with all convenient speede'. ${ }^{135}$ Hilliard's treatise was therefore possibly intended for the same educated audience as Haydocke's translation of Lomazzo, which was published whilst Haydocke was still a student at Oxford. ${ }^{136}$ That Hilliard's words are intended for a restricted audience is certainly emphasised in his opening statement of intent to 'shewe who are fittest to be practisers' (p. 62). Yet Hilliard speaks not of the gentle painter, but of the professional visual artist who must adopt gentility as part of his professional practice. Accounting for the attributes of limners, Hilliard remarks:

it is convenient that they be gentlemen of good parts and ingenuity, either of ability, or made by prince's fee able so to carry themselves as to give such seemly attendance on princes as shall not offend their royal presence. Seest thou not that these men, then, must often in their business stand before princes, though they be born but common people? But God, the author of wisdom and the giver of all 
good gifts and goodness, He giveth gentility to divers persons, and raiseth man to reputation by divers means. (p. 65)

Hilliard's interpretation of the relationship between professional limning and gentility becomes tangled as he insists that limning is an inherently gentle practice. Since gentlemen are not practitioners of professional making, Hilliard must invoke a divinely ordained social mobility in order to reconcile the presence of those 'born but common people' in the practice of a mode of representation that 'tendeth not common men's use' (pp. 63-5). Hilliard does not find it contradictory to imagine that a 'prince's fee' might be a manifestation of this divine mobilisation of social identity.

Concerns about the social implications of the intimate access to the sitter that a painter might enjoy are explored in the plays of this period. In Campaspe, Apelles is ordered to paint the portrait of Alexander the Great's Theban captive, Campaspe, and falls in love with her as she sits for the picture in his 'shop' (III.v.68). To an extent, this depiction of painterly transgression reflects the common trope of the tailor as a sexually transgressive figure who exploits unusually intimate access to the bodies of male and female clients. ${ }^{137}$ That Apelles regularly enjoys painting attractive women in intimate privacy is suggested by his boy, Psyllus, who explains that 'it is always my master's fashion, when any fair gentlewoman is to be drawn within, to make me stay without' (III.ii.1-3). It is important to point out here that a painter's 'client' is not always equivalent to the sitter for the painting; Alexander is the patron here, rather than Campaspe. Apelles's transgression in falling in love with his monarch's object of desire is therefore equivalent to an act of social disobedience, the painter consequently fearing that he may 'perish' as a result of his love (V.ii.5). As this example suggests, the hierarchical dynamics of patronage provide a fitting context for carnivalesque comedy that draws on the social anxieties attendant on the act of image-making. In The Wisdom of Doctor Dodypoll, a comedy first printed in 1600 and probably first performed around that date, Earl Lassingbergh poses as a painter in the home of a jeweller, Flores, in order to be close to his daughter, Lucilia, whose 'glorious parts' he paints with delight. ${ }^{138}$ In this instance, then, the gentleman painter poses as a professional workman in the employ of a non-gentle character. The play opens with Lassingbergh 'painting' as Lucilia 'sits working on a piece of cushion work' (I.i.3-4SD). This is not an instance of Lucilia sitting for her portrait; instead, the aristocrat-as-painter uses Lucilia's body as the model for the disparate body parts that contribute to 'Antickes' (I.i.21). Lassingbergh is therefore painting the kind of decorative work seen in Rowland Buckett's designs for the organ at Hatfield House. Lassingbergh includes Lucilia's body parts amidst an antic design comprising flowers, jewels and figures from classical mythology: 
Form these base Anticks where my hand hath spearst

Thy severall parts: if I uniting all,

Had figur'd there, the true Lucilia,

Then might'st thou justly wonder at mine Art,

And devout people would from farre repaire,

Like Pilgrims, with their dutuous sacrifice,

Adorning thee as Regent of their loues;

Here, in the Center of this Mary-gold,

Like a bright Diamond I enchast thine eye.

Here, underneath this little Rosie bush

Thy crimson cheekes peers forth more faire then it.

Here, Cupid (hanging downe his wings) doth sit,

Comparing Cherries to thy Ruby lippes:

Here is thy browe, thy haire, thy neck, thy hand,

Of purpose all in severall shrowds disper'st:

Least ravisht, I should dote on mine owne worke,

Or Envy-burning eyes should malice it. (I.i.50-66)

The dispersal of Lucilia's body parts in the antic design here facilitate highly sexualised exchanges between Lucilia and Lassingbergh. The painter suggests that he has hidden her 'parts' in 'severall shrowds' because the unification of these elements would cause him to 'ravish' the painting. The fragmentation of Lucilia's body is therefore presented as a preventative tactic that withholds an anticipated moment of Pygmalion-like idolatry. Aesthetic unity is here both desirable and fearful, a 'just' reflection of the Earl's 'art' but provocative of sexual, social and spiritual transgression. Lassingbergh's deployment of antic work is a crucial aspect of his disguise, and, as L. E. Selmer notes, 'preserves the secrecy of his passion'. ${ }^{139}$ The Earl's allusion to what might be achieved aesthetically and risked morally in the 'uniting' of Lucilia's 'parts' suggests that he more usually paints in a naturalistic, figurative style. That this style may be socially appropriate in other contexts where the sitter is not a social inferior is suggested by the apparent fame of Lassingbergh's work. In Act 2 the painter's identity is discovered when Prince Alberdure, whose name is thought to allude to Albrecht Dürer, admires 'The cunning strangenes' of the 'antick worke' in Flores's home, stating that 'though the generall tract of it be rough / Yet is it sprinckled with rare flowers of Art' (II.i.354-5). ${ }^{140}$ Alberdure invites the opinion of Motto, 'a practitioner', who concludes:

My Lord, I thinke more Art is shaddowed heere,

Then any man in Germanie can shew,

Except Earle Lassingbergh; and (in my conceipt)

This worke was never wrought without his hand. (II.i.371-4)

That Lassingbergh is 'discovered' to be an aristocrat as the result of the viewing of his work by elite figures connects nobility with skill in visual 
representation. This connection is advanced by the Earl's opening speech, which situates his work as a part of a divine, natural order. Lucilia laments that Lassingbergh must appear as 'a mercenary painter', to which the Earl responds:

A Painter faire Lucia? Why the world

With all her beautie was by painting made.

Looke on the heavens colour'd with golden starres,

The firmamentall ground of it, all blew.

Looke on the ayre, where with a hundred changes

The watry Rainbow doth imbrace the earth.

Looke on the sommer fields adorn'd with flowers,

How much is natures painting honour'd there?

Looke in the Mynes, and on the Easterne shore,

Where all our Mettalls and deare Jems are drawne:

Thogh faire themselves, made better by their foiles.

Looke on that litle world, the twofold man,

Whose fairer parcell is the weaker still:

And see what azure vaines in stream-like forme

Divide the Rosie beautie of the skin.

I speake not of the sundry shapes of beasts,

The severall colours of the Elements:

Whose mixture shapes the world's varietie,

In making all things by their colours knowne.

And to conclude, Nature her selfe divine,

In all things she hath made, is a meere Painter. (I.i.24-44)

Lassingbergh's activities as a painter are here envisaged as an extension of the natural work of earthly creation. Since the social structure was also considered to be natural, Lassingbergh's painterliness is therefore produced by the same divine structure which generates his nobility. In this view, the Earl's skill as a 'maker' is a consequence of earthly creation and a facet of elitism.

The social status of image-makers remained a preoccupation for dramatists decades later, as is demonstrated by Richard Brome's The Court Beggar, probably first performed between 1640 and $1641 .{ }^{141}$ Here, Mr Dainty, a pickpocket, poses as a painter, and proposes a monopoly on sign-painting to the foolish knight, Sir Andrew Mendicant:

DAINTY Sir, I am a picture-drawer, limner, or painter (if you please) and would gladly purchase authority, by myself and deputies, for the painting of all the king'sand queen's-head signs for taverns, inns, ale-houses, and all houses and shops of trade throughout the kingdom upon this ground: that they draw and hang up their royal images for signs in so hideous manner that men bless themselves to see't. Mendicant Aye, marry, this hangs upon some ground. But are you an exquisite workman in that art, sir?

DAINTY I am an artist in that mystery, sir, and have drawn some of His Majesty’s 
pictures, by copy only but so to the life that gentlemen have kneeled to 'em for suits and knighthoods. ${ }^{142}$

Dainty's assertion that he is a limner makes a mockery of the refined craft of the miniaturist, since he claims to be nothing more than a sign-painter who draws the king second-hand. Dainty's boast that his representations deceive the eye matches the deceit that he practises on the gullible Mendicant, and Brome's depiction of a pickpocket who claims to be a painter chimes with postReformation concerns about the reliability of visual experience. In The Wisdom of Doctor Dodypoll, the social elite maintain a modicum of authority within the social unruliness of the play-world. Lassingbergh's disguise, for example, is discerned by the aesthetically well-informed Alberdure and his courtly train, but is at first inscrutable to the non-gentle Flores, who is convinced that Lassingbergh is 'but a simple man kept in my house', whose skill as a painter is 'obscur'd by needie povertie' (II.i.361-2). In The Court Beggar, in contrast, Mendicant is easily deceived by Dainty's disguise. As Marion O'Connor explains, this 'tricksy' play 'refuses a stable position' from which it may condemn or celebrate Caroline politics. ${ }^{143}$ From this elusive standpoint, the play explicitly addresses the 'proliferation of monopolies' around the time of the Short Parliament of 1640, as Mendicant is a 'monopolist' as well as a knight who, at the conclusion of the drama, according to a stage direction, appears 'attired all in patents' as a part of a chaotic anti-masque (5.2. Speeches 1104-5). ${ }^{144}$ Dainty's suggested monopoly on sign-painting therefore partakes of Brome's commentary on a volatile moment of social disintegration, as Mendicant the 'old Knight' transforms into a 'Projector'. ${ }^{145}$ Significantly, this commentary on monopolies sees Brome policing the boundaries of his own profession. During the 1630s, tensions rose amongst professional dramatists angered by the activities of self-funded, aristocratic playwrights such as Sir John Suckling, who paid for the performance of his play Aglaura at the Blackfriars theatre in 1638, and also subsidised the publication of the drama in an expensive folio, satirised by Brome in the poem 'Upon Aglaura in Folio'. ${ }^{146}$ Suckling is ridiculed throughout The Court Beggar in the figure of Sir Ferdinand, an 'Exquisite cavalier, courtier and soldier, / Scholar (and what not!)', while the exclusion of non-professional playwrights from the theatre is entertained in Mr Court-Wit's proposal that only plays by those 'who profess or endeavour to live by the quality' be 'admitted to the stage' (1.1. Speech 15; Epilogue, 2. Speech 368). ${ }^{147}$

How does the contested social status of the professional visual artist or writer relate to the makings of non-professional, elite figures? To consider this question it is worth looking at the example of the aristocratic hive of creativity that was the family of Mildmay Fane, second Earl of Westmoreland, during the late sixteenth century and well into the seventeenth century. Mildmay 
Fane's grandmother, Grace, Lady Mildmay, produced a medical guide and Lady Mildmay's Meditations, a manuscript containing maternal advice prepared between 1603 and 1617-20. ${ }^{148}$ The latter manuscript was supplemented by other relatives to become A Book of Advice to the Children, presented to Mildmay Fane and his younger brother, Francis. ${ }^{149}$ Grace, Lady Mildmay's granddaughter, Rachel Fane, was a similarly prolific writer; 'one of the few women at the time to learn secretary hand with any fluency', she was probably responsible for the transcription of her grandparents' advice in A Book of Advice to the Children. ${ }^{150}$ Rachel Fane's surviving notebooks contain recipes, sermon notes, translations and a fragment of a masque that was probably written when she was thirteen or fourteen. ${ }^{151}$ O'Connor suggests that it is a 'virtual certainty' that the masque was 'performed sometime between December 1626 and July 1627' at the family home, Apethorpe Hall, Northamptonshire. ${ }^{152}$ The children of the family starred in this lively production, which had been carefully designed by Rachel Fane, her stage directions for example suggesting that the production conclude with the masquers dancing 'a dance of my making'. ${ }^{153}$ Rachel Fane also seems to have made her own games; a playing card showing the Queen of Diamonds, and inscribed 'Rachel', survives in the Kent Archives, Maidstone. ${ }^{154}$

The family were also engaged in architectural and sculptural acts of making. In his will, Sir Anthony Mildmay (d. 1617) requested that a monument be built in St Leonard's church, Apethorpe, this being paid for through the sale of Lincolnshire land. ${ }^{155}$ The monument, attributed to Maximilian Colt, stands in a south chapel that was specially made to house it in 1621 (figures 7 and 8). Also installed in the chapel in 1621 was a stained-glass window, attributed to Baptista Sutton, showing Adam and Eve in the Garden of Eden, the Crucifixion and Judgement Day (figure 9). ${ }^{156}$

In 1622-24, Rachel Fane's father, Francis Fane, first Earl of Westmorland, undertook a major programme of building at Apethorpe in order to accommodate visits by James I, Anne of Denmark and Prince Charles. ${ }^{157}$ As Jennifer S. Alexander and Kathryn A. Morrison have established, the remodelling of the hall was probably carried out by the workshop of local mason Thomas Thorpe, who had also been involved with building work at Blickling Hall, Norfolk, in $1618-23 .{ }^{158}$ The Fanes' cultural production is spread between individualistic writings and large-scale commissions for built structures which required interaction with numerous professional artificers. Out of this context of diffuse literary productivity and architectural remaking emerges the most well known of the Fane family, Mildmay Fane, a prolific poet who also wrote masques to be performed at Apethorpe by family members and servants. Amongst these masques, which survive in manuscript form in the British Library, Raguillo D'Oceano includes a detailed stage design that demonstrates knowledge of cutting-edge stage practice, showing 'oblique side wings' of the sort used by Inigo Jones in the last of the Caroline court masques, Salmacida Spolia (1640). ${ }^{159}$ The stage designs 


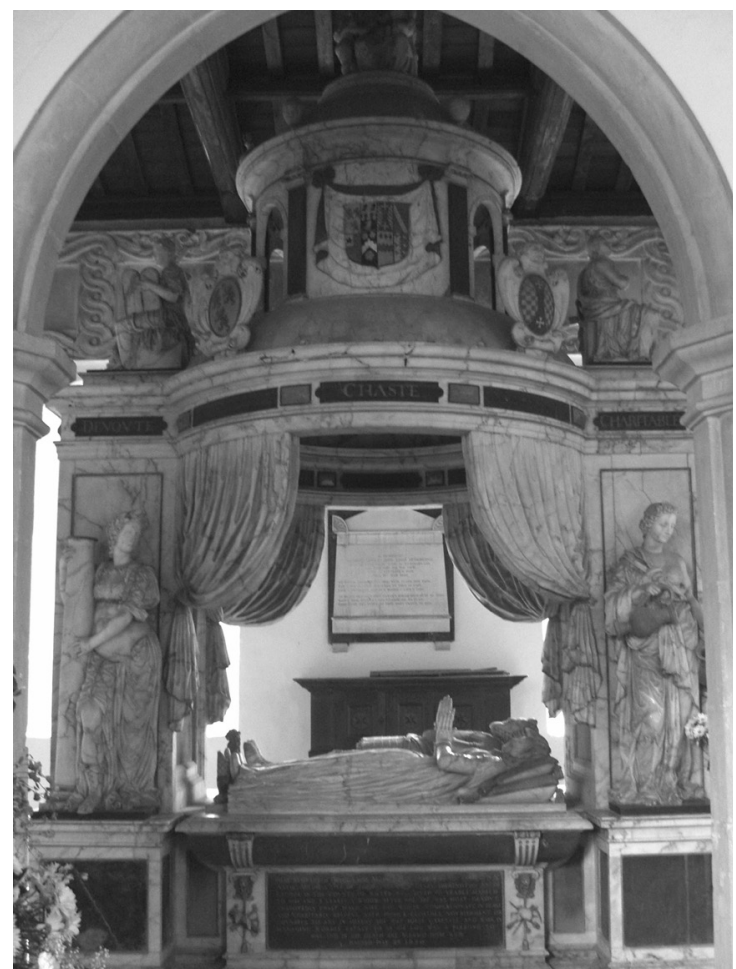

7 The Mildmay monument, attr. Maximilian Colt (1621), Church of St Leonard, Apethorpe, England

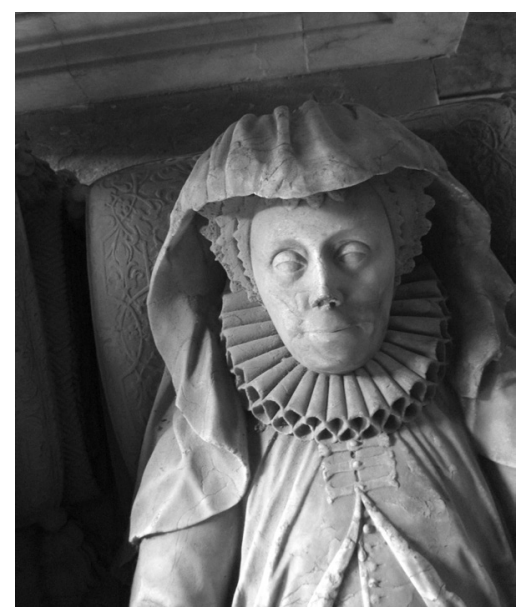

8 Detail of sculpture of Grace, Lady Mildmay, the Mildmay monument, attr. Maximilian Colt (1621), Church of St Leonard, Apethorpe, England 


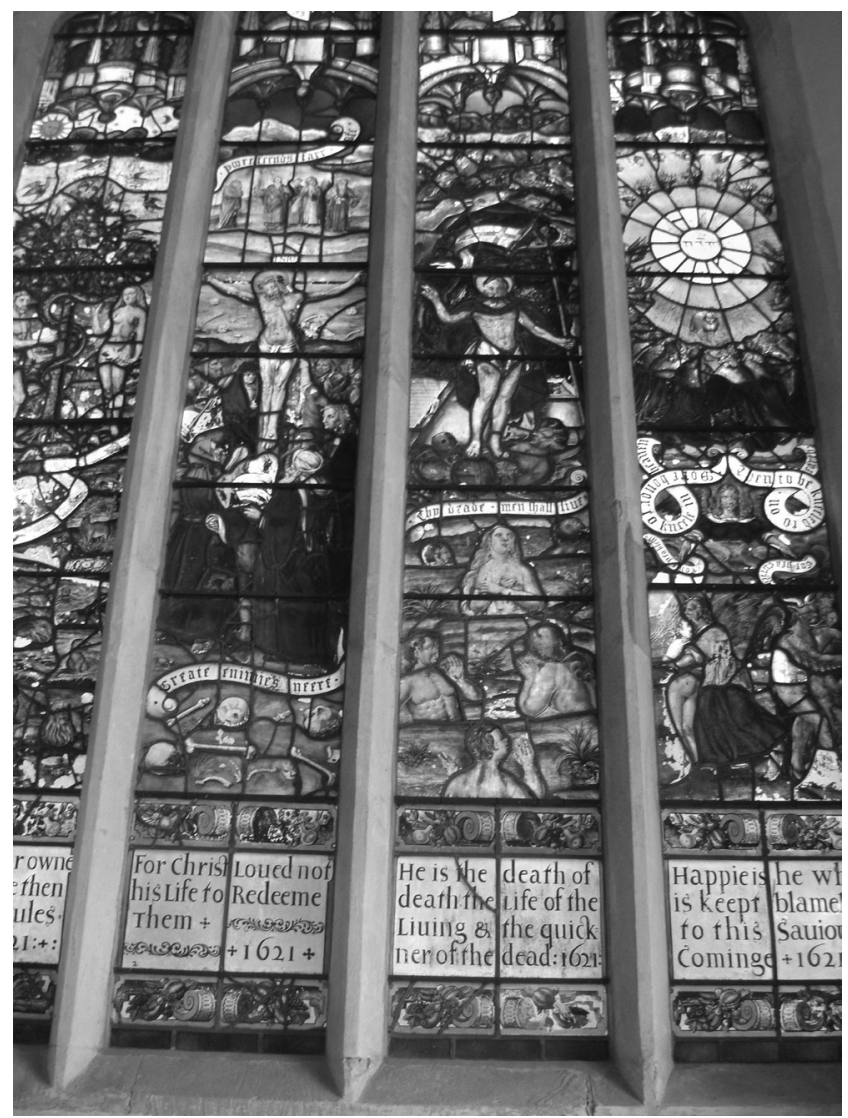

9 Painted glass window, attr. Baptista Sutton (1621), Church of St Leonard, Apethorpe, England

for Fane's masques also deploy the language of the published scripts of court masques; a visually less-detailed design for the masque Candy Restored, describes a scene rendered 'in perspective' showing 'a goodly fabrick or Cittie the Emblem of Concord Unitie and peace'. ${ }^{160}$ Fane was the first English peer to publish his poetry, in the collection Otia Sacra (1648), but, unlike Sir John Suckling, did not publish any masques or plays. ${ }^{161}$

Writing after the closure of the London theatres that produced such professional-amateur tensions, Mildmay Fane depicts professional 'makers' in a mode that appropriates the comic figure of the artisan in an expression of anxiety at the social and political turmoil of the 1640s. Fane was imprisoned in the Tower of London between August 1642 and April 1643, and, while there, wrote the short masque The Change, which was probably never performed. In Scene 5 of The Change, the 'old felonious world' of the early seventeenth 
century is tried by a jury comprising two merchants, two women enthusiastic for drastic change, and ten artisans including 'Sim Seinemaker', also known as 'Mr Discoverye', 'Sam Shark, Saylor', 'Tim Fit Round-Buttonmaker' and 'Batt Basketmaker'. ${ }^{162}$ That the Fanes were fond of these reductive tropes of artisanship is suggested by the fact that one 'Captain Sharke one of the fleete' is also a character in a later Fane masque, Pugna Anima (1650). ${ }^{163}$ In The Change, the court is presided over by a half-French, half-Italian madman, Cappritcio, and the possibility of artisans influencing the social and cosmological order is ridiculed. ${ }^{164}$ The trial is held in the vernacular for the benefit of the jury, and each of the artisans is introduced with a comic reflection on their profession and status. 'Batt Baskettmaker', for example, declares that the 'world is soo growne' with 'pride' to be seen in the company of a basketmaker, but also claims that 'fools and women' are 'of my Congregation'. ${ }^{165}$ The connection between the artisans and the Parliamentarian cause is signalled as each artisan is associated with 'round' items, such as the 'Charles Capper', the Haberdasher's 'Capp of haire' that 'shall not be square, it shall be Rounde'. ${ }^{166}$ Although imprisoned because of his support for the king, Mildmay Fane was not the most committed Royalist, pledging allegiance to the Commonwealth in 1643 and spending much of his time after 1645 on his estates. ${ }^{167}$ Writing in the Tower, however, Fane expresses dismay at political events through the carnivalesque figure of the artisan, so distinct from his and his family's identities as makers of literature, monuments, buildings, games and performances.

Taken with Brome's The Court Beggar, The Change suggests the intricate relationship between social hierarchy and the status and agency of those who are implicated in cultural production. The mid seventeenth century was of course a time of great change for drama, and in the past the 1640s have figured as a kind of endpoint for studies of drama and visual culture. Diehl, for example, suggested that dramatists' attempts to 'reform the stage' made them complicit in the suppression of playing that led to the closure of the playhouses in $1642 .{ }^{168}$ The mid seventeenth century also often looms as a moment of change for studies in this area because this period is associated with the development of Cartesian ways of seeing the world and the self. ${ }^{169}$ Knapp, for example, explores aesthetic experience and ethical choice in Shakespearean drama with an eye on the 'transition' to Cartesian models of vision in the later part of the seventeenth century. ${ }^{170}$ In this study I do not aim to challenge the meanings that are attached to the mid seventeenth century as a time of political, social and scientific change, and nor do I intend to provide a history of the development of attitudes to making and unmaking from the late sixteenth century and up until that moment of supposed 'change'. The latest play to be studied in this book, The Two Merry Milkmaids, was first performed in 1619, and I am concerned with fermenting ideas about aesthetic experience as these relate to the pressures of early modern English social hierarchy. Since that social hierarchy came under 
revolutionary pressure in the 1640s, my analysis implicitly gestures towards this historical moment as a point of possible aesthetic change. Perhaps appropriately for a book concerned with unfinished things, I gesture towards this implication but do not arrive at it in full. This is in part because I am attracted to Harris's understanding of early modern matter as shaped by 'polychronic' time, and consider, as explained in the Introduction, that it would be inappropriate to impose a chronological, linear structure on this discussion. ${ }^{171}$

At the same time, however, that seventeenth-century 'change' hovers in the far distance throughout this book, even as I explore the ways in which concepts of cultural production in drama constantly turn in on themselves as they refuse notions of stable 'finish'. This is partly because this study is concerned with a divinely ordained social hierarchy that destabilises aesthetic ends. This socially shaped aesthetic instability is suggested in The Wisdom of Doctor Dodypoll in Lassingbergh's resistance to an aesthetic 'unity' that is rendered inaccessible because his practice as a painter is connected to the inversion of social order. Lassingbergh considers his painting an extension of divine, natural creativity, but the Earl's need to adopt a disguise that includes painting in an 'antic' style betrays the socially inflected limitations attendant on image-making. What means of legitimisation were necessary for image-makers who were not of the status of an earl? The examples of visual artists and 'creative' figures discussed to this point have been largely elite, or, like Hilliard, employed by the elite. Did professional artisans 'make' literary or visual works for their own enjoyment? Was there what Shiner might refer to as a 'proto-aesthetic' amongst this community? ${ }^{172}$ It is extremely difficult to ascertain an answer to this question because very little evidence of artisans' textual or pictorial output survives, as it does for an aristocratic family such as the Fanes. ${ }^{173} \mathrm{~A}$ pertinent example is the two compendious miscellanies made by the craftsman Thomas Trevilian (or Trevelyon), which are known as the Miscellany (1608) and the Great Book (1616). ${ }^{174}$ These huge works combine written extracts from a wide variety of sources with colourful illustrations, many of which Trevilian is thought to have copied 'while they hung in shops in Blackfriars, the Strand and elsewhere'. ${ }^{175}$ For example, in a section entitled 'The miser of mans life: Dye to Live', and 'The misery of mans life: Live to Dye', versions of which appear in both the Miscellany and Great Book, Trevilian combines religious verse with conventional memento mori iconography, including an image of a shrouded corpse copied from Richard Day’s A Booke of Christian Prayers (1578) (figures 10 and 11). ${ }^{176}$

The humble sense of mortality asserted in these images reflects the humility with which Trevilian introduces his Great Book, in an epistle to the reader. Trevilian explains:

I tooke this labour in hande to accomplish my minde, to pleasure my friendes ... For what I have done hath bin of my selfe without mans teaching, God onlye 


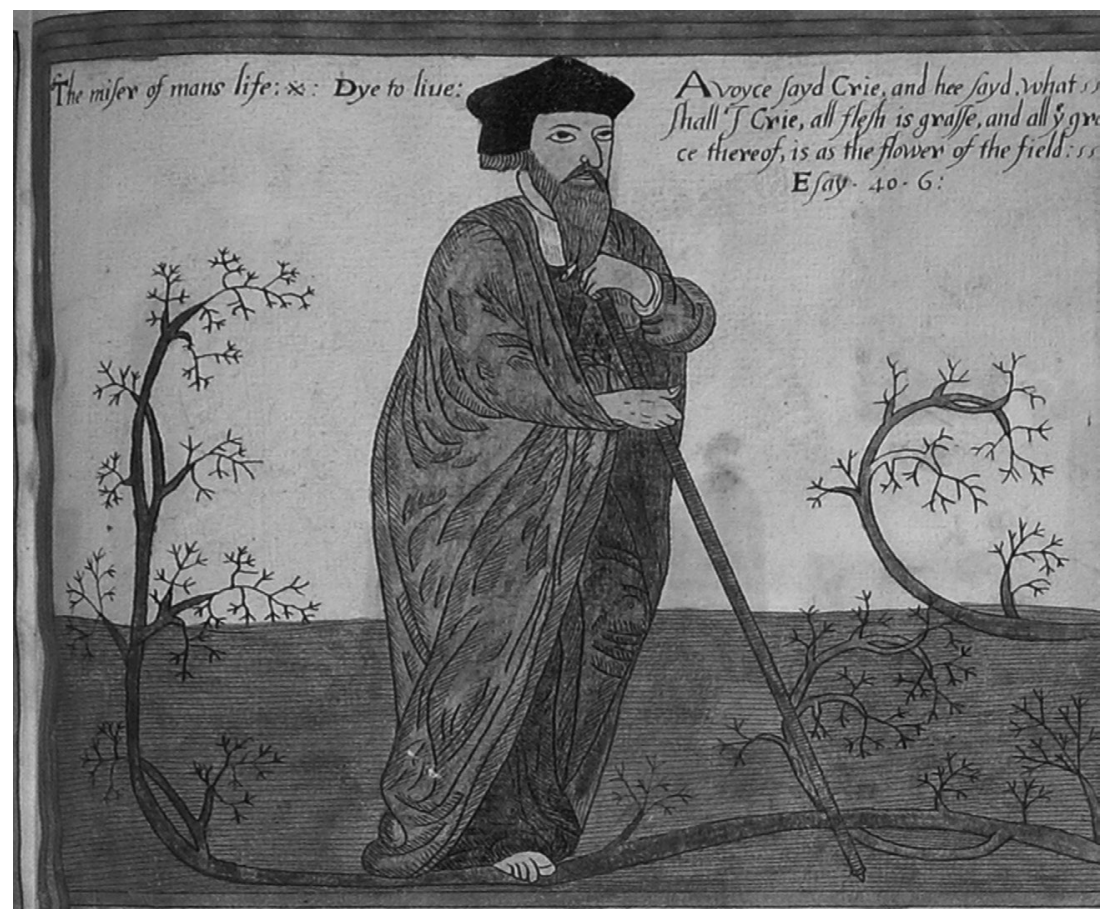

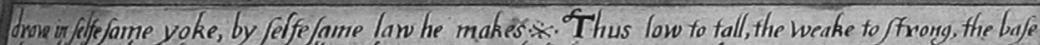

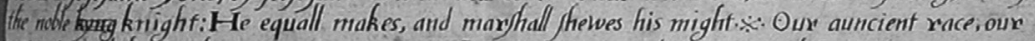
ifts of mind, hie noght refpect our yeeres: He is not mooved to vertuous life, neplaints or prayen. renes: And yef this comforfe fill we haue, this hope is left behind: Whereof we thinking,

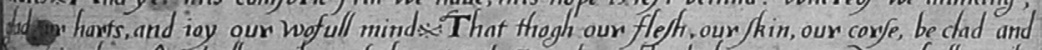

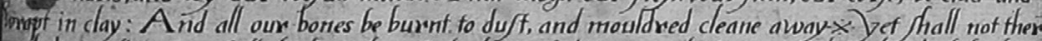
wir bodies frill, in fearef ull darkines lye: Like brutigh beaffes, whofe fence and Joules, doth batth at re time dyexBut mightry. God from death beloe, fo life a bour will raije: And cloth our bones

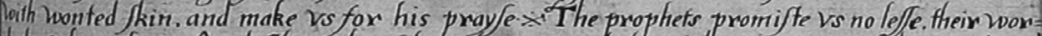
ts do toch it plain: And Chinift himf folfe in louing fort, dectares sthe fame againex. The facred wond confirmes ý fame, to Lifich they credite give. That hope to haue the farry pole, in enlefe iny to liue:

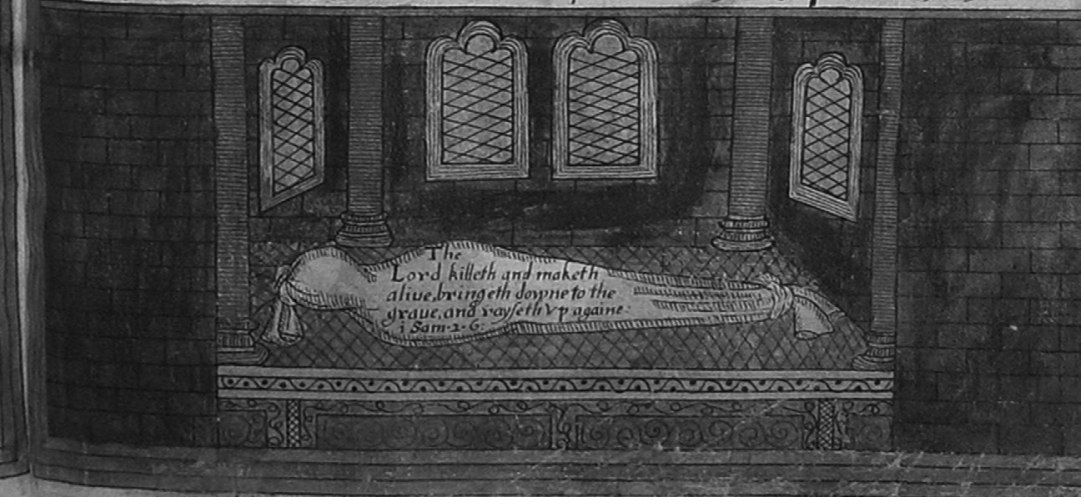

10 Thomas Trevilian, 'The miser of mans life: Dye to live', The Great Book (1616), fol. 371r 


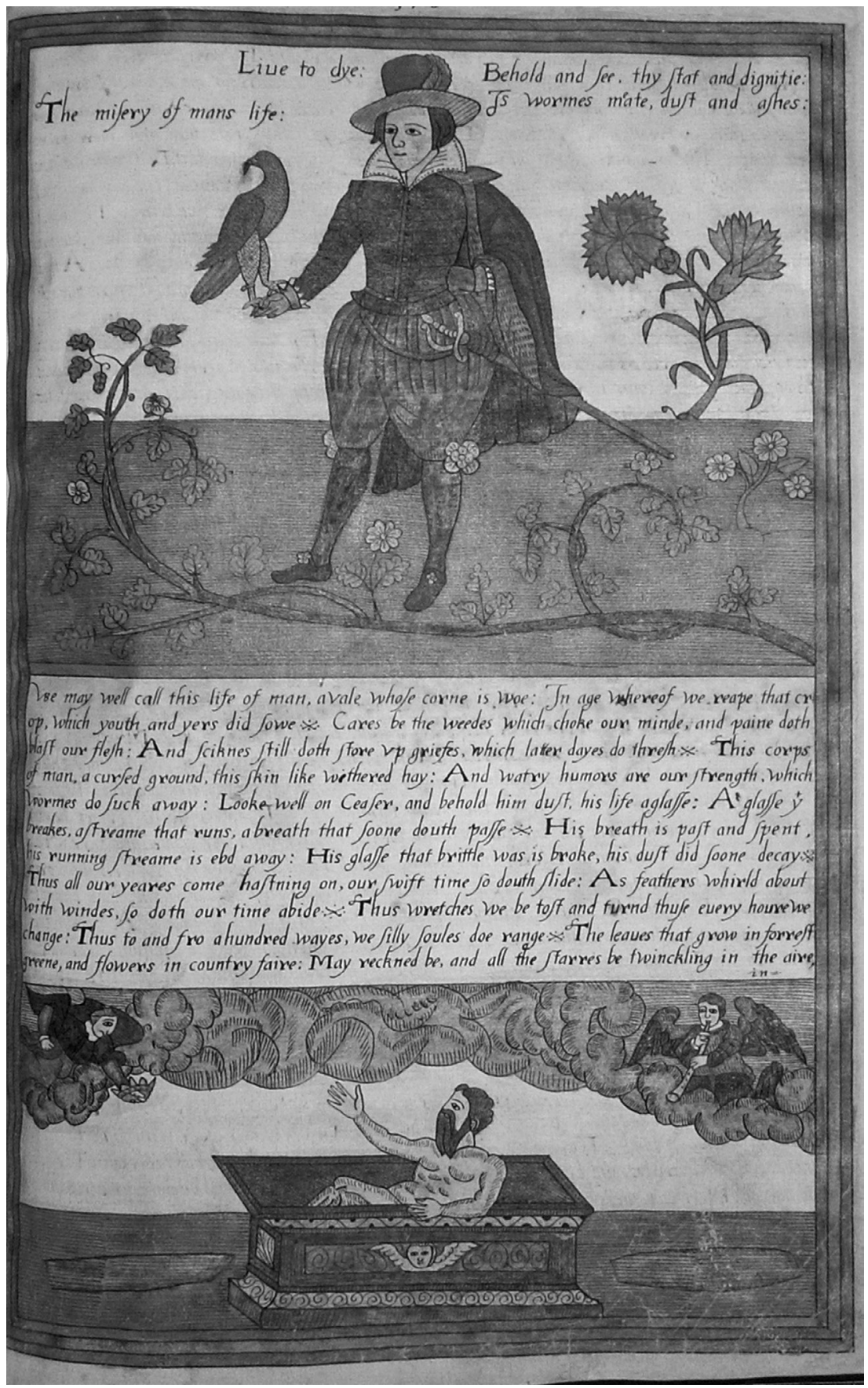

11 Thomas Trevilian, 'The misery of mans life: Live to dye', The Great Book (1616), fol. 375r 
infusing his celestiall blessings: And though I in my rashenesse presume to write this booke, yet I trust in gathering the fragments and broken sentences, as a beginning unto others that are better stored, it will be of some considered, though of others defamed and mocked. ${ }^{177}$

Trevilian here adopts the apologetic tones that are a familiar aspect of early modern prefatory writings such as the prologue to Shakespeare's Henry V. Echoing that prologue, Trevilian draws attention to the imperfection of his work, a collection of 'fragments and broken sentences', and gestures towards the future improvement of this fragmentary assemblage by his readers, to whom the Great Book is offered 'as a beginning'. The self-taught, independent act of bringing together and then reproducing such a compendious collection of words and images requires qualification, as Trevilian deferentially admits the 'rashenesse' of his presumption in producing the text and presenting it to be read. This letter to the reader encourages us to see the Great Book as made within the conventions of literary patronage. Indeed, it has been suggested that Trevilian may have been commissioned to produce a pattern book by William Herbert, third Earl of Pembroke, or may have made a pattern book that he intended to dedicate to Pembroke. ${ }^{178}$ The latter parts of both the Miscellany and the Great Book are devoted to beautiful motifs, lettering and alphabet designs and patterns which would have been used 'for embroidery, marquetry and other applied arts'. ${ }^{179}$ But what is the relationship between these patterns and the earlier parts of the miscellanies, which seem intended as didactic sources of 'edification and entertainment'? ${ }^{180}$ Heather Wolfe observes that what is unusual about Trevilian's Miscellany is its 'color, size and range of multimedia material'; otherwise, the text draws on the widespread early modern practice of miscellanising or commonplacing. ${ }^{181}$ Significantly, Wolfe also suggests that the 'fragments and broken sentences' assembled by Trevilian reflect his efforts to 'create order, beauty, and continuity out of the fracture and stress caused by his country's growing pains' ${ }^{182}$ If this is the case, then in the Great Book, Trevilian presents the attainment of this order as beyond his grasp as a craftsman who has worked 'without man's teaching' and only with 'celestial blessings'.

Gesturing towards an 'end' that is beyond his reach, Trevilian presents his work as unfinished as an act of deference. Perhaps this deference is to an aristocratic figure such as Pembroke. Even if this is the case, however, Trevilian's attitude to his work as aesthetically fragmented is generated by the craftsman's position within a social hierarchy understood as divinely ordered. In this way, Trevilian's introduction to the incompletion of his Great Book marks the perfect point at which to end this chapter, demonstrating that aesthetic 'finish' is a socially inflected property. At the same time, Trevilian's Great Book suggests that the 'end' was attainable in a material sense, as the author states that he 'made an end' of the text in 1616. Of course, this 'end' signalled the completion of a work that is an 
altered version of the 1608 Miscellany. Amidst the social anxieties attendant on the idea of 'finish', the declaration of a material 'end', and the intricacies of Trevilian's textual practice, this craftsman's miscellanies reflect the complex relationship between material activity, social status and aesthetic concepts in this period. Moreover, the uncertainty regarding Trevilian's audience and his relationship to a possible patron create the sense that his miscellanies are unique, and arguably overemphasise our sense of his status as an individual, originary 'author'. In the next chapter, I show that the hierarchical nature of the patronage of the visual arts provides a context through which Shakespeare explores the contested status of material 'finish', and the agency of image-makers and their audiences alike.

\section{Notes}

1 Shiner, The Invention of Art, p. 12.

2 See James Elkins, Visual Studies: A Skeptical Introduction (New York and London: Routledge, 2003), pp.2, 36. See also Michael Baxandall, Painting and Experience in Fifteenth-Century Italy: A Primer in the Social History of Pictorial Style (Oxford: Clarendon Press, 1972).

3 Lucy Gent, “"The Rash Gazer”: Economies of Vision in Britain, 1550-1660', in Lucy Gent (ed.), Albion's Classicism: The Visual Arts in Britain, 1550-1660, Studies in British Art, 2 (New Haven: Yale University Press for the Paul Mellon Centre for Studies in British Art and the Yale Center for British Art, 1995), pp.382-3, pp. 377-94. See also Juliet Fleming, Graffiti and the Writing Arts of Early Modern England (London: Reaktion, 2001), pp.32-3.

4 Robert Tittler, 'Buckett, Rowland (bap. 1571, d. 1639)'. Oxford DNB. www. oxforddnb.com/view/article/101262. Accessed 8 April 2012. See also Anthony Wells-Cole, Art and Decoration in Elizabethan and Jacobean England: The Influence of Continental Prints, 1558-1625 (New Haven: Yale University Press, for the Paul Mellon Centre for Studies in British Art, 1997), pp. 32, 207.

5 Wells-Cole, Art and Decoration, p. 32.

6 Wells-Cole, Art and Decoration, p. 32.

7 John Florio, A Worlde of Wordes, Anglistica \& Americana Reprints (Hildesheim: George Olms Verlag, Zürich, 2004), p. 157.

8 Tittler, 'Buckett, Rowland'.

9 Tittler, 'Buckett, Rowland'.

10 See Tracey Hill, Pageantry and Power: A Cultural History of the Early Modern Lord Mayor's Show, 1585-1639 (Manchester: Manchester University Press, 2010), pp. 76-7; see also Tittler, 'Buckett, Rowland'.

11 F. P. Wilson and R. F. Hill (eds), Collections X: 'Dramatic Records in the Declared Accounts of the Office of the Works, 1560-1640' (Oxford: Malone Society Reprints, 1975), pp. 43, 24-5. The 'Cockpitt' is the Cockpit-in-Court at Whitehall, redesigned by Inigo Jones in 1629; on this court theatre, see Glynne Wickham, Early English Stages 1300 to 1660, vol. 2: 1576 to 1660, Part II, $2^{\text {nd }}$ edition (1959; London: Routledge, 2002), pp. 119-22. 
12 See Peacock, The Stage Designs of Inigo Jones, p. 6.

13 Wilson and Hill (eds), Collections X, p. 41.

14 Henry Peacham, The Gentlemans Exercise (London: John Browne, 1612), title page, and Graphice or The Most Ancient and Excellent Art of Drawing and Limning disposed into three Bookes (London: printed by W. S. for John Browne, 1612), title page. EEBO. http:/ / eebo.chadwyck.com. Accessed 29 December 2012.

15 Henry Peacham, The Compleat Gentleman Fashioning him absolute in the most necessary \& Commendable Qualities concerning Minde or Bodie that may be required in a Noble gentleman (London: Francis Constable, 1622), sig. A2r. EEBO. http:// eebo.chadwyck. com. Accessed 29 December 2012.

16 John Bate, The Mysteryes of Nature, and Art: Conteined in foure severall Tretises, The first of Water workes the second of Fyer workes, The third of Drawing, Colouring, Painting, and Engrauing, The fourth of divers Experiments, as wel Serviceable as delightful: partly Collected, and partly of the Authors Peculiar Practice, and Invention, by J. B (London: printed by Ralph Mab to be sold by John Jackson and Francis Church, 1634), pp. 101, 149.

17 Bate, Mysteryes, p. 109.

18 Elkins, Visual Studies, p. 4.

19 Michael O'Connell, The Idolatrous Eye: Iconoclasm and Theater in Early-Modern England (New York: Oxford University Press, 2000), p. 144.

20 Raymond Williams, Keywords: A Vocabulary of Culture and Society (1976; London: Fontana, 1988), p. 87.

21 Eamon Duffy, The Stripping of the Altars: Traditional Religion in England 1400-1580, $2^{\text {nd }}$ edition (1992; New Haven and London: Yale University Press, 2005), pp. 155-6.

22 See Phillips, The Reformation of Images, p. 25.

23 Francis Cheetham, English Medieval Alabasters: With a Catalogue of the Collection in The Victoria \& Albert Museum, new edition (1984; Woodbridge: Boydell, 2005), p. 28; see also Duffy, Stripping of the Altars, p. 233.

24 Phillips, The Reformation of Images, p. 41.

25 Phillips, The Reformation of Images, p. 41, and see also pp. 10-21, 30-40 for a useful account of pre-Reformation image debates in England. For a history of image controversies that draws on Greek, Judaic, Islamic and Christian contexts, see Besançon, The Forbidden Image.

26 See Phillips, The Reformation of Images, pp. 62-79, 89-90, 95-6, 106-7, 115-17.

27 See Aston, England's Iconoclasts, pp.220-342, and her Faith and Fire: Popular and Unpopular Religion, 1350-1600 (London: Hambledon Press, 1993), pp. 262-89.

28 Clark, Vanities of the Eye, p. 15; Michael Camille, 'Before the Gaze: The Internal Senses and Late Medieval Practices of Seeing', in Robert S. Nelson (ed.), Visuality Before and Beyond the Renaissance: Seeing as Others Saw (Cambridge: Cambridge University Press, 2000), pp. 197-223, pp. 208-9. On gender in medieval theories of vision, see Katharine Park, 'Impressed Images: Reproducing Wonders', in Caroline A. Jones and Peter Galison (eds), Picturing Science, Producing Art (New York and London: Routledge, 1998), pp. 254-71.

29 Clark, Vanities of the Eye, pp. 43-4.

30 Clark, Vanities of the Eye, p. 44. 
31 Phillips, The Reformation of Images, p. 55.

32 See Phillips, The Reformation of Images, pp. 55, 92; see also Clark, Vanities of the Eye, p. 163.

33 Stephen Gosson, Playes Confuted in Five Actions, Proving that they are not to be suffered in a Christian common weale, by the way both the Cavils of Thomas Lodge, and the Play of Playes, written in their defence, and other objections of Players frendes, are truely set downe and directlye aunsweared (London: Thomas Gosson, 1582), sig. C1r. EEBO. http:// eebo.chadwyck.com. Accessed 29 March 2012.

34 See for example Tassi, The Scandal of Images, p. 31.

35 Huston Diehl, Staging Reform, Reforming the Stage: Protestantism and Popular Theater in Early Modern England (Ithaca and London: Cornell University Press, 1997), p. 8.

36 Diehl, Staging Reform, p. 217.

37 Diehl, Staging Reform, p. 2.

38 Patrick Collinson, 'From Iconoclasm to Iconophobia: The Cultural Impact of the Second English Reformation', The Stenton Lecture, 1985 (Reading: University of Reading, 1986), p. 8.

39 James A. Knapp, Illustrating the Past in Early Modern England: The Representation of History in Printed Books (Aldershot: Ashgate, 2003), pp. 16-19, 75-6, and his Image Ethics, p. 34.

40 See Tessa Watt, Cheap Print and Popular Piety, 1550-1640, Cambridge Studies in Early Modern British History (Cambridge: Cambridge University Press, 1991), passim.

41 Hamling and Williams, 'Introduction', pp. 1, 4. I refer to 'Britain' here following Hamling and Williams's use of this term. I discuss the significance of Hamling and Williams's work for literary studies in 'Idolatry, Iconoclasm and Agency: Visual Experience in Works by Lyly and Shakespeare', Literature \& History, 18 (2009), 1-15.

42 Hamling, Decorating the 'Godly' Household, p. 7.

43 Hamling, Decorating the 'Godly' Household, pp. 158-9.

44 Hamling, Decorating the 'Godly' Household, p. 159.

45 Hamling, Decorating the 'Godly' Household, p. 221.

46 Andrew Gurr, The Shakespearean Stage, 1574-1642, $3^{\text {rd }}$ edition (1992; Cambridge: Cambridge University Press, 2003), p. 75.

47 Belsey, Shakespeare and the Loss of Eden, p. 13.

48 Collinson, 'Iconoclasm to Iconophobia', p. 8.

49 Hamling and Williams, 'Introduction', p. 4.

50 Stacy Boldrick and Richard Clay, 'Introduction', in Stacy Boldrick and Richard Clay (eds), Iconoclasm: Contested Objects, Contested Terms (Aldershot: Ashgate, 2007), pp.1-14, p.9. See also essays in this collection by Charles Ford, Richard Clay, Alexandrina Buchanan, Adrian A. Bantjes, Hans Georg Hiller von Gaertringen, Polly Jones and Ramon Sarró.

51 Boldrick and Clay, 'Introduction', p. 9.

52 Michael Wayne Cole and Rebecca Zorach, 'Introduction', in Michael Wayne Cole and Rebecca Zorach (eds), The Idol in the Age of Art: Objects, Devotions and the Early Modern World (Aldershot: Ashgate, 2009), pp.1-10, p.2. The emphasis is in the text.

53 Fabio Rambelli and Eric Reinders, 'What does Iconoclasm Create? What Does 
Preservation Destroy? Reflections on Iconoclasm in East Asia', in Stacy Boldrick and Richard Clay (eds), Iconoclasm: Contested Objects, Contested Terms (Aldershot: Ashgate, 2007), pp. 15-33, pp.17-18.

54 C. Pamela Graves, 'From an Archaeology of Iconoclasm to an Anthropology of the Body: Images, Punishment and Personhood in England, 1500-1660', Current Anthropology, 46:1 (2008), 35-57, 35.

55 On the defacement at Salthouse, see Robert Whiting, The Reformation of the English Parish Church (Cambridge: Cambridge University Press, 2010), pp. 17-18.

56 Graves, 'From an Archaeology of Iconoclasm', 37-8; see also Duffy, Stripping of the Altars, p. 431, and Julie Spraggon, Puritan Iconoclasm during the English Civil War, Studies in Modern British Religious History (Woodbridge: Boydell Press, 2003) pp. 207-8.

57 See John Clifford, The Ensigns of the Twelve Tribes of Israel, St Lawrence Parish Church booklet, pp. 1-3. See also Watt, Cheap Print, p. 161, n. 116.

58 Clifford, The Ensigns, p. 1.

59 Clifford, The Ensigns, pp. 1-2.

60 John Day, William Rowley and George Wilkins, The Travels of the Three English Brothers, in Three Renaissance Travel Plays, ed. Anthony Parr, The Revels Plays Companion Library (Manchester: Manchester University Press, 1995), Prologue, $30-1$.

61 John Ford, The Broken Heart, in John Ford: Three Plays, ed. Keith Sturgess (Harmondsworth: Penguin, 1970), Epilogue, 5-14.

62 The dating of the Chorus speeches in Henry $V$ has been subject to debate; see Richard Dutton, "'Methinks the truth should live from age to age": The Dating and Contexts of Henry V', Huntington Library Quarterly, 68:1-2 (2005), 173-204.

63 William Shakespeare, Henry V, ed. T. W. Craik, The Arden Shakespeare, third series (London: Routledge, 1995), Prologue, 10-31. All subsequent references are to this edition.

64 John Wycliffe, The Rule of St. Francis (?1430), in Frederic D. Matthew, The English works of Wyclif hitherto unprinted (London: Trübner \& co. for the English Text Society, 1880), quoted in the OED.

65 Jones and Stallybrass, Renaissance Clothing, p. 26.

66 Jones and Stallybrass, Renaissance Clothing, p. 24.

67 Jones and Stallybrass, Renaissance Clothing, p. 23.

68 Stern, Documents of Performance, p. 1.

69 George Puttenham, The Arte of English Poesie (1589; Menston: Scolar Press, 1968), p. 104. This is the earliest usage of to 'piece out' quoted in the OED.

70 Matthew Milner, The Senses and the English Reformation, St Andrews Studies in Reformation History (Farnham: Ashgate, 2011), pp. 7-8.

71 Stern, Documents of Performance, pp. 113-14.

72 Andrew Gurr, Playgoing in Shakespeare's London, $3^{\text {rd }}$ edition (1987; Cambridge: Cambridge University Press, 2004), p. 1; see also Charles Whitney, Early Responses to Renaissance Drama (Cambridge: Cambridge University Press, 2006), p. 5.

73 See Anthony B. Dawson and Paul Yachnin, The Culture of Playgoing in Shakespeare's England: A Collaborative Debate (Cambridge: Cambridge University Press, 2001). 
See also Paul Menzer, 'Crowd Control', in Jennifer A. Low and Nova Myhill (eds), Imagining the Audience in Early Modern Drama, 1558-1642 (New York: Palgrave Macmillan, 2011), pp. 19-36, pp. 23-4.

74 Dawson and Yachnin, The Culture of Playgoing, p. 5.

75 Whitney, Early Responses, p. 5. See also Lopez, Theatrical Convention, pp. 18-19.

76 See Gurr, Playgoing, pp. 107-16; see also Brian W. Schneider, The Framing Text in Early Modern English Drama: 'Whining' Prologues and 'Armed' Epilogues (Farnham: Ashgate, 2011), pp.71-91. Lopez warns against over-attention to 'the surface impression of more rigidly segregated audiences ... than the evidence actually yields up', Theatrical Convention, p. 16.

77 Ben Jonson, Bartholomew Fair, ed. Susan Gossett, Revels Student Editions (Manchester: Manchester University Press, 2000), Induction, 66. All subsequent references are to this edition.

78 Ben Jonson, The Staple of News, ed. Anthony Parr, The Revels Plays (Manchester: Manchester University Press, 1988), Prologue for the Stage, 1-6.

79 See Judith Dundas, 'Ben Jonson and the Paragone', Sixteenth Century Journal, 9 (1978), $56-65$.

80 For a discussion of this dispute, see D. J. Gordon, 'Poet and Architect: The Intellectual Setting of the Quarrel between Ben Jonson and Inigo Jones', in The Renaissance Imagination: Essays and Lectures by D. J. Gordon, ed. Stephen Orgel (Berkeley: University of California Press, 1975), pp. 77-101.

81 Sir Philip Sidney, The Countesse of Pembrokes Arcadia (London: John Windet for William Ponsonbie, 1590), sig. V1r. EEBO. http:/ / eebo.chadwyck.com. Accessed 7 September 2012.

82 See Gurr, Playgoing, p. 109.

83 Gurr, Playgoing, p. 109.

84 Thomas Becon, The new pollecye of warre wherein is declared not only how ye mooste cruell tyrant the great Turke may be over come, but also all other enemies of the Christian publique weale, lately devised by Theodore Basille (London: John Maylerre for John Gough, 1542), sig. B4r. See also Seymour Baker House, 'Becon, Thomas (1512/13-1567)'. Oxford DNB. www.oxforddnb.com/view/article/1918. Accessed 18 September 2012.

85 Katharine Eisaman Maus, Inwardness and Theater in the English Renaissance (Chicago: University of Chicago Press, 1994), p. 210.

86 Knapp, Image Ethics, p. 2.

87 Elizabeth Spiller, 'Shakespeare and the Making of Early Modern Science: Resituating Prospero's Art', South Central Review, 26:1-2 (2009), 24-41, 27. Spiller takes the phrase 'maker's knowledge tradition' from Antonio Pérez-Ramos, Francis Bacon's Idea of Science and the Maker's Knowledge Tradition (Oxford: Oxford University Press, 1988).

88 Spiller, 'Shakespeare and the Making of Early Modern Science', 27.

89 Spiller, 'Shakespeare and the Making of Early Modern Science', 27.

90 See Jean E. Howard, 'Cross-dressing, the Theater, and Gender Struggle in Early Modern England', in Lesley Ferris (ed.), Crossing the Stage: Controversies on Crossdressing (London: Routledge, 1993), pp.20-46, p.21; see also Stephen Orgel, 
Impersonations: The Performance of Gender in Shakespeare's England (Cambridge: Cambridge University Press, 1996), pp. 26-30.

91 The italics are Gossett's, reflecting italicisation in the play as published in the 1640 second folio of Jonson's works, which used a version of the play prepared for publication in 1631. On the play's textual history see Jonson, Bartholomew Fair, ed. Gossett, pp. 20-1.

92 Maus, Inwardness and Theater, p. 210.

93 Maus, Inwardness and Theater, p. 34; on new-historicist approaches to spectatorship, see Nova Myhill and Jennifer A. Low, 'Introduction: Audience and Audiences', in Jennifer A. Low and Nova Myhill (eds), Imagining the Audience in Early Modern Drama, 1558-1642 (New York: Palgrave Macmillan, 2011), pp. 1-17, pp. 2-3.

94 See Maus, Inwardness and Theater, p. 210.

95 Aura Satz, 'Attacks on Automata and Eviscerated Sculptures', in Stacy Boldrick and Richard Clay (eds), Iconoclasm: Contested Objects, Contested Terms (Aldershot: Ashgate, 2007), pp. 35-49, pp. 45-7.

96 Lynn Enterline, 'Afterword: Touching Rhetoric', in Elizabeth D. Harvey (ed.), Sensible Flesh: On Touch in Early Modern Culture (Philadelphia: University of Pennsylvania Press, 2003), pp. 243-54, p. 248.

97 Johnson, Mother Tongues, p. 53.

98 Harris, Untimely Matter, p. 8. Jacques Derrida writes that 'it is because arche-writing, movement of differance, irreducible arche-synthesis, opening in one and the same possibility, temporalization as well as relationship with the other and language, cannot, as the condition of all linguistic systems, form a part of the linguistic system itself and be situated as an object in its field', Of Grammatology, trans. Gayatri Chakravorty Spivak, corrected edition (Baltimore and London: Johns Hopkins University Press, 1997), p. 60.

99 Richard Haydocke, A tracte containing the artes of curious paintinge carving and building written first in Italian by Io: Paul Lomatius painter of Milan and Englished by R. H student in physic (Oxford: Joseph Barnes for R. H., 1598), $95 \mathrm{r}-\mathrm{v}$.

100 See for example Gent, Picture and Poetry, p. 2; Thorne, Vision and Rhetoric, p. 44; Kiefer, Shakespeare's Visual Theatre, p. 1; Tassi, The Scandal of Images, p. 60; Knapp, Illustrating the Past, p. 81.

101 Stephen Orgel, 'What is a Text?', in David Scott Kastan and Peter Stallybrass (eds), Staging the Renaissance: Reinterpretations of Elizabethan and Jacobean Drama (New York and London: Routledge, 1991), pp. 83-7, pp. 85-6.

102 Gordon McMullan, Shakespeare and the Idea of Late Writing: Authorship in the Proximity of Death (Cambridge: Cambridge University Press, 2007), p. 233.

103 McMullan, Shakespeare and the Idea of Late Writing, p. 233.

104 Robert Tittler, Portraits, Painters, and Publics in Provincial England, 1540-1640 (Oxford: Oxford University Press, 2012), p.68. Tittler draws here on the 'Making Art in Tudor Britain' project at the National Portrait Gallery, London, which is led by Tarnya Cooper; see National Portrait Gallery. www.npg.org.uk/research/programmes/making-art-in-tudor-britain.php. Accessed 30 October 2012.

105 Orgel, 'What is a Text?', p. 85. On collaborative patrons in Europe see Lorne Campbell, Renaissance Portraits: European Portrait-Painting in the $14^{\text {th }}, 15^{\text {th }}$ and $16^{\text {th }}$ 
Centuries (New Haven and London: Yale University Press, 1990), pp. 139-47. There is a great deal of literature on patronage of the visual arts in early modern Italy. See, for example, Mary Hollingsworth, Patronage in Renaissance Italy: From 1400 to the Early Sixteenth Century (Baltimore: Johns Hopkins University Press, 1994), and her Patronage in Sixteenth-Century Italy (London: John Murray, 1996); Creighton E. Gilbert, 'What Did the Renaissance Patron Buy?', Renaissance Quarterly, 51:2 (1998), 392-450, and Michelle O’Malley, The Business of Art: Contracts and the Commissioning Process in Renaissance Italy (New Haven: Yale University Press, 2005).

106 Tittler, Portraits, Painters, and Publics, p. 125.

107 Hamling, Decorating the 'Godly' Household, p. 20; see also Malcolm Airs, The Making of the English Country House, 1500-1640 (London: Architectural Press, 1975), and his The Tudor and Jacobean Country House: A Building History (Stroud: Sutton Publishing, 1995).

108 Nigel Llewellyn, Funeral Monuments in Post-Reformation England (Cambridge: Cambridge University Press, 2000), p. 277.

109 These figures were usually involved in commissions by 'female patrons and grander patrons', Llewellyn, Funeral Monuments, pp. 164-5, 276-9.

110 Llewellyn, Funeral Monuments, pp. 165-7, 279-82.

111 Donne's monument forms a part of Jones and Stallybrass's discussion of the materiality of memory in Renaissance Clothing, pp. 252-5.

112 See Izaak Walton, The Life of John Donne, Dr. in Divinity, and Late Dean of Saint Pauls Church London (London: printed by J. G. for R. Marriot, 1658), pp.111-13; see also Helen Gardner, 'Dean Donne's Monument in St Paul's', in René Wellek and Alvaro Ribeiro (eds), Evidence in Literary Scholarship (Oxford: Clarendon Press, 1979), pp. 29-44. Llewellyn does not question Walton's account, Funeral Monuments, p. 235.

113 Anon, $4^{\text {th }}$ Addition, in Thomas Kyd, The Spanish Tragedy, ed. David Bevington, Revels Student Editions (Manchester: Manchester University Press, 1996), 153-60.

114 Anon, The Spanish Tragedy, $4^{\text {th }}$ Addition, 115-36.

115 See Diehl, Staging Reform, pp. 112-14. For a response to Diehl's argument on the place of 'incarnational ways of thinking' in Elizabethan theatre, see Dawson and Yachnin, The Culture of Playgoing, pp. 21-9.

116 Anon, The Spanish Tragedy, $4^{\text {th }}$ Addition, 144-5, 170SD.

117 See Robert Tittler, The Face of the City: Civic Portraiture and Civic Identity in Early Modern England (Manchester: Manchester University Press, 2008), especially pp. 37-68.

118 See Hill, Pageantry and Power, pp. 53-117, and David M. Bergeron, English Civic Pageantry 1558-1642 (London: Edward Arnold, 1971), pp. 243-308.

119 See Joseph Loewenstein, Ben Jonson and Possessive Authorship (Cambridge: Cambridge University Press, 2002); see also Douglas A. Brooks, From Playhouse to Printing House: Drama and Authorship in Early Modern England (Cambridge: Cambridge University Press, 2000), pp. 104-39. Stephen B. Dobranski builds on Brook's work in his Readers and Authorship in Early Modern England (Cambridge: Cambridge University Press, 2005), p. 101.

120 Clark, Vanities of the Eye, p. 163. 
121 See Jones and Stallybrass, Renaissance Clothing, p. 188.

122 Gurr, Shakespearean Stage, p. 7. See Cedric C. Brown (ed.), Patronage, Politics and Literary Traditions in England 1558-1658 (Detroit: Wayne State University Press, 1993); C. Warley, Sonnet Sequences and Social Distinction in Renaissance England (Cambridge: Cambridge University Press, 2005).

123 Tittler, Portraits, Painters, and Publics, p. 60.

124 Tittler, Portraits, Painters, and Publics, pp. 61-2.

125 Tittler, Portraits, Painters, and Publics, p. 60.

126 Thomas Hoby, The courtyer of Count Baldessar Castilio divided into foure bookes (London: Wyllyam Seres, 1561), sig. J3v.

127 Peacham, The Compleat Gentleman, sig. P3r.

128 Christy Anderson discusses BL, Sloane MSS 536, in 'The Secrets of Vision in Renaissance England', in Lyle Massey (ed.), The Treatise on Perspective: Published and Unpublished, Studies in the History of Art 59, Centre for the Advanced Study in the Visual Arts, Symposium Papers XXXVI (New Haven and London: Yale University Press for the National Gallery of Art, Washington, 2003), pp.323-47, pp. 333-9.

129 Anderson, 'The Secrets of Vision', p. 339.

130 Peacham, The Art of Drawing with the Pen and Limning in Water Colours, more exactlie than heretofore taught, and enlarged with the true manner of Painting upon glasse, the order of making your furnace, Annealing \& c (London: Richard Braddock for William Jones, 1606), p. 3. EEBO. http:/ / eebo.chadwyck.com. Accessed 22 December 2012. Gent discusses the popularity of drawing amongst men of gentle and aristocratic status because, unlike painting, 'it did not involve messy colours' and 'was the tool of arts and sciences', Picture and Poetry, p. 11.

131 See Peacham, The Art of Drawing, title page, and The Gentlemans Exercise, p. 4.

132 See William Eamon, Science and the Secrets of Nature: Books of Secrets in Medieval and Early Modern Culture (Princeton: Princeton University Press, 1994), p. 307.

133 Steven A. Walton, 'Bate, John (fl. 1626-1635)', Oxford DNB. www.oxforddnb.com/ view/article/53656. Accessed 4 November 2012.

134 See R. K. R. Thornton and T. G. S. Cain, 'Introduction', in Nicholas Hilliard, A Treatise Concerning The Arte of Limning, by Nicholas Hilliard, together with A More Compendious Discourse Concerning ye Art of Limning by Edward Norgate (Ashington and Manchester: Mid Northumberland Arts Group in association with Carcanet Press, 1981), p. 17. All subsequent references are to this edition. 'Limning' refers to miniature painting; see Roy Strong, The English Renaissance Miniature (London: Thames \& Hudson, 1983), and Graham Reynolds, English Portrait Miniatures (Cambridge: Cambridge University Press, 1988).

135 Haydocke, Tracte containing the artes of curious paintinge, sig. $\mid 6 \mathrm{r}$. See also Thornton and Cain, 'Introduction', in Hilliard, Arte of Limning, pp. 17-18.

136 See Sarah Bakewell, 'Haydock, Richard (1569/70-c. 1642), Physician', Oxford DNB, www.oxforddnb.com/view/article/12746. Accessed 9 June 2007.

137 See Simon Shepherd, “What's So Funny about Ladies' Tailors?”: A Survey of Some Male (Homo)Sexual Types in the Renaissance', Textual Practice, 6:1 (1992), 17-31.

138 Anon, The Wisdome of Doctor Dodypoll, ed. M. N. Matson (New York and London: Garland, 1980), I i.10. All subsequent references are to this edition. 
139 L. E. Selmer, 'Breaking the Ice to Invention: Henry Peacham's The Art of Drawing (1606)', The Sixteenth Century Journal, 35:3 (2004), 735-50, 747.

140 See Tassi, The Scandal of Images, p. 121.

141 On the date of the composition and first performance of this play, see Marion O'Connor, 'The Court Beggar: A Critical Introduction', The Court Beggar, paragraph 28, Richard Brome Online. www.hrionline.ac.uk/brome. Accessed 14 April 2012.

142 Richard Brome, The Court Beggar (1640-42), ed. Marion O’Connor, (2. Speeches 379-81). Richard Brome Online. www.hrionline.ac.uk/brome. Accessed 14 April 2012. All subsequent references are to this edition.

143 O'Connor (ed.), 'The Court Beggar', paragraph 40.

144 See Martin Butler, Theatre and Crisis: 1632-1642 (Cambridge: Cambridge University Press, 1984), pp. 16, 135-6.

145 O'Connor (ed.), 'The Court Beggar', paragraph 40.

146 Tom Clayton, 'Suckling, Sir John (bap. 1609, d. 1641?)'. Oxford DNB www. oxforddnb.com/view/article/26757. Accessed 18 March 2012. Brome's poem was included before the Prologue of The Weeding of Covent Garden, in Richard Brome, Five new playes, viz. The English moor, or the mock-marriage. The love-sick court, or the ambitious politique: Covent Garden weeded. The new academy, or the new exchange. The queen and concubine (London: A. Cook, 1659), unpaginated. See O'Connor (ed.), 'The Court Beggar', paragraph 20 and note 11599.

147 O'Connor (ed.) 'The Court Beggar', paragraphs 8, 20-5.

148 Edith Snook, 'Maternal Advice', in Caroline Bicks and Jennifer Summit (eds), The History of British Women's Manuscript Writing, 1500-1610, vol. 2 (Basingstoke: Palgrave Macmillan, 2010), pp.108-29, p.113. Linda A. Pollock, 'Mildmay, Grace, Lady Mildmay (c. 1552-1620). Oxford DNB. www.oxforddnb.com/view/article/ 45817. Accessed 18 September 2010.

149 Snook, 'Maternal Advice', p. 115.

150 Caroline Bowden, 'The Notebooks of Rachel Fane: Education for Authorship?', in Victoria E. Burke and Jonathan Gibson (eds), Early Modern Women's Manuscript Writing: Selected Papers from the Trinity/Trent Colloquium (Aldershot: Ashgate, 2004), pp. $157-80$, p. 162.

151 Bowden, 'The Notebooks of Rachel Fane', pp. 164-5.

152 Marion O’Connor, 'Rachel Fane's May Masque at Apethorpe, 1627', English Literary Renaissance, 36:1 (2006), 90-113, 96.

153 Rachel Fane, 'Rachel Fane’s May Masque at Apethorpe, 1627', ed. Marion O'Connor, English Literary Renaissance, 36:1 (2006), 105-13, 112.

154 See O’Connor, 'Rachel Fane’s May Masque', 93.

155 'Probate Will of Sir Anthony Mildmay dated 14 Feb. 1614 Proved 11 Oct. 1617' MS Westmorland (A) 1.ix.1, Northamptonshire Record Office.

156 See Graham Parry, Glory, Laud and Honour: The Arts of the Anglican CounterReformation (Woodbridge: Boydell Press, 2006), pp.102-3. See also Hamling, Decorating the 'Godly' Household, pp. 58-9.

157 See Jennifer S. Alexander and Kathryn A. Morrison, 'Apethorpe Hall and the Workshop of Thomas Thorpe, Mason of King's Cliffe: A Study in Mason's Marks', Architectural History, 50 (2007), 59-94, 59. 
158 Alexander and Morrison, 'Apethorpe Hall', 71, 74.

159 See Barbara Ravelhofer, The Early Stuart Masque: Dance, Costume and Music (Oxford: Oxford University Press, 2006), p.94. See also Mildmay Fane, Raguillo D’Oceano, in 'Six Comedies Performed at the Earl of Westmoreland's Seat at Apethorpe, co. Northampton, by the children and servants of the family', MS ADD 34221, British Library. Following Clifford Leech, I use the British Museum pagination; see Clifford Leech, Mildmay Fane's Raguaillo D'Oceano, 1640, and Candy Restored, 1641, edited from the London and Huntington Manuscripts (Louvain: Librarie Univerditaire, 1983), p. 5.

160 Mildmay Fane, Candy Restored, in 'Six Comedies Performed at the Earl of Westmoreland's Seat at Apethorpe, co. Northampton, by the children and servants of the family', MS ADD 34221, British Library, p. 2.

161 See Tom Cain (ed.), The Poetry of Mildmay Fane, Second Earl of Westmoreland (Manchester: Manchester University Press, 2000), p. 1.

162 Mildmay Fane, The Change, in 'Six Comedies Performed at the Earl of Westmoreland's Seat at Apethorpe, co. Northampton, by the children and servants of the family', MS ADD 34221, British Library. See Leech, Mildmay Fane's Raguaillo D'Oceano, pp. 45-7.

163 Mildmay Fane, Pugna Anima, in 'Six Comedies Performed at the Earl of Westmoreland's Seat at Apethorpe, co. Northampton, by the children and servants of the family', MS ADD 34221, British Library, fol. 125r.

164 Fane, The Change, fol. 58v; see also Leech, Mildmay Fane's Raguaillo D'Oceano, p. 46.

165 Fane, The Change, fol. 62r-v.

166 Fane, The Change, fol. 64r.

167 Stephen Wright, 'Fane, Mildmay, Second Earl of Westmorland (1602-1666)'. Oxford DNB. www.oxforddnb.com/view/article/9139. Accessed 11 May 2012. As Leech notes, Fane's political sympathies in The Change are highly ambiguous, Veering 'from one side to the other with a rather bewildering rapidity', Mildmay Fane's Raguaillo D'Oceano, p. 47.

168 Diehl, Staging Reform, p. 215.

169 On Descartes, optics and cognition in light of the history of early modern vision, see Clark, Vanities of the Eye, pp. 333-56.

170 Knapp, Image Ethics, p. 12.

171 Harris, Untimely Matter, p. 10.

172 Shiner, The Invention of Art, p. 53.

173 For an anthology of surviving artisan writings, see James S. Amelang, The Flight of Icarus: Artisan Autobiography in Early Modern Europe (Stanford: Stanford University Press, 1998).

174 In using these titles I follow Heather Wolfe (ed.), The Trevelyon Miscellany of 1608: A Facsimile of Folger Shakespeare Library MS V.b.232 (Washington, DC: Folger Shakespeare Library, 2007). In my use of the spelling ‘Trevilian’ I follow Nicholas Barker (ed.), The Great Book of Thomas Trevilian: A facsimile of the Manuscript in the Wormsley Library, 2 vols (London: Roxburghe Club, 2000). All subsequent references to The Great Book are to vol. 2 of this edition unless otherwise indicated.

175 Wells-Cole, Art and Decoration, p. 235.

176 Trevilian, Miscellany, fols 180r-1r, and The Great Book, pp. 371, 375. See also Richard 
Day, A Booke of Christian Prayers, collected out of the ancient writers, and best learned in our tyme, worthy to be read wyth an earnest mynde of all Christians, in these daungerous and troubleseome dayes, that God for Christes sake will yet still be mercyfull unto us (London: John Daye, 1578), sig. Y3r.

177 Trevilian, The Great Book, p.2, quoted in Wolfe (ed.), Miscellany, p. 8. This prefatory material is not included in the Miscellany, but, as Wolfe notes, 'the first four pages (fols 1-2)' of the Miscellany, 'which are no longer extant, may have originally contained such matter', Miscellany, p. 8, fig. 1. The page which includes this passage is not included in Nicholas Barker's facsimile of The Great Book. My thanks to Nick Peate of the Wormsley Library for his assistance with this reference.

178 Wolfe (ed.), Miscellany, pp. 11-12.

179 Wells-Cole, Art and Decoration, p. 235; Trevilian, Miscellany, fols 215r to 307v. John L. Nevinson refers to Trevilian as a 'scrivener', in 'A Show of the Nine Worthies', Shakespeare Quarterly, 14:2 (1963), 103-7, 103.

180 Wolfe (ed.), Miscellany, p. 8.

181 Wolfe (ed.), Miscellany, p. 8.

182 Wolfe (ed.), Miscellany, p. 7. 